$$
\begin{aligned}
& \text { RECEIVED } \\
& \text { AUG } 271998 \\
& \text { S T }
\end{aligned}
$$

ORNL/TM-13655

OAK RIDGE NATIONAL LABORATORY
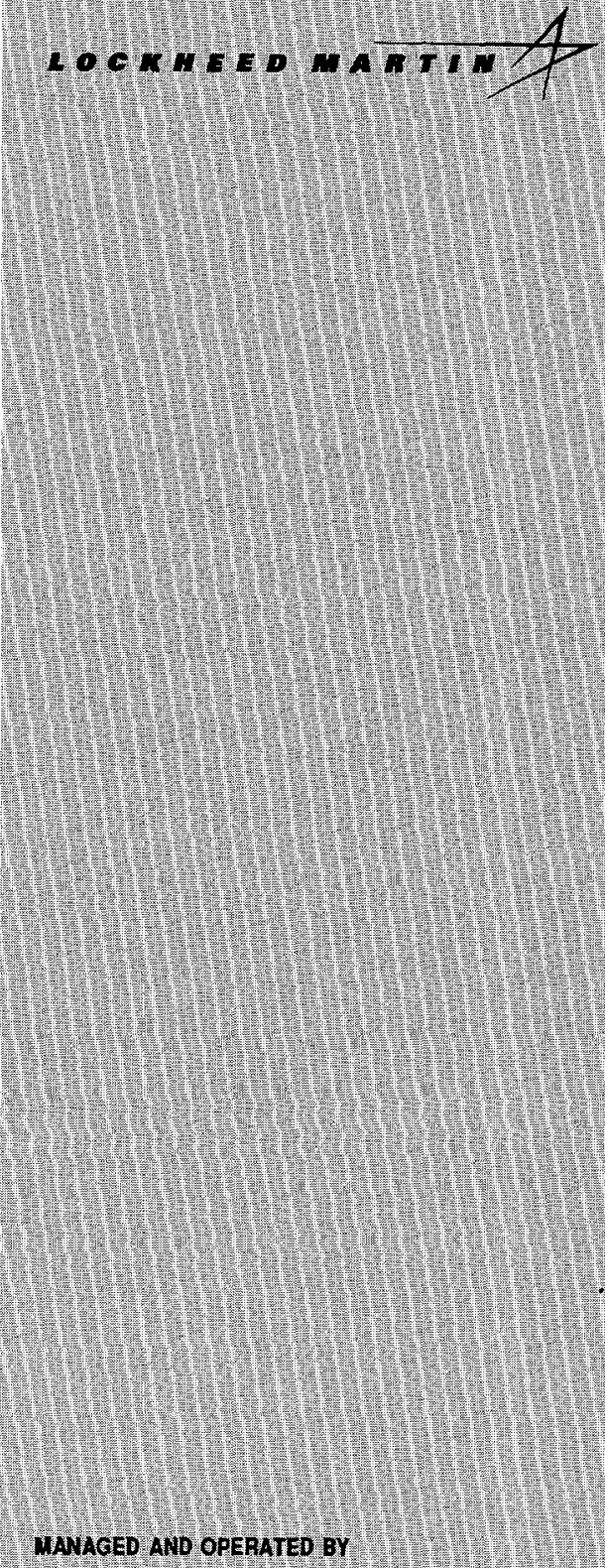

WHAGED AMD OPERATED BY

LOCKHEED MARTN EMERGY RESEARCH COBPORATION FOA THE UNTED STATES

DEPARTMENT OF ENERGY

\section{Water Washes and Caustic Leaches of Sludge from Hanford Tank S-101 and Water Washes of Sludge from Hanford Tank C-103}

\author{
R. D. Hunt \\ J. L. Collins \\ C. W. Chase
}


This report has bern reproduced directly from the best available copy.

Available to DOE and DOE contractors from the Office of Scientific and Technical Informetion, P.O. Box 62, Oak Ridge. TN 37831; prices available from (615) 576-8401, FTS 626-8401.

Available to the public from the National Technical Information Service, U.S. Department of Cormerce, 5285 Port Royal Rd., Springfield, VA 22161.

This report was Jepared as an account of work sponsored by an agency of the United Statesi Government. Neither the United States Government nor any agency thereof, nor any of their employees, makes any warranty, express or implied, or assunies any logal liability or responsibility for the accuracy, com pleteness, or uselulness of any information, apparatus, product, or process disclosed, or repre:sents that its use would not infringe privately owned rights. Reference herein to any specific commercial product, process, or service by trade name, tradimark, manufacturer, or otherwise, does not necesserily constitute or imply its endorsement, recommendation, or favoring by the United States Government or any agency thereof. The views and opinions of authors expressed herein do not necessarily state or reflect those of the United States Government or aryy agency thereof. 


\section{DISCLAIMER}

Portions of this document may be illegible in electronic image products. Images are produced from the best available original document. 


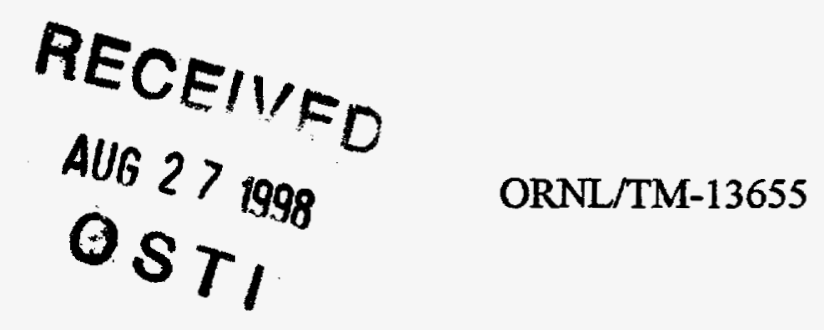

Chemical Technology Division

Water Washes and Caustic Leaches of Sludge from Hanford Tank S-101 and Water Washes of Sludge from Hanford Tank C-103
R. D. Hunt
J. L. Collins
C. W. Chase

Date Published: July 1998

\author{
Prepared by the \\ OAK RIDGE NATIONAL LABORATORY \\ Oak Ridge, Tennessee 37831-6285 \\ managed by \\ LOCKHEED MARTIN ENERGY RESEARCH CORP. \\ for the \\ U.S. DEPARTMENT OF ENERGY \\ under contract DE-AC05-960R22464
}




\section{CONTENTS}

LIST OF TABLES $\ldots \ldots \ldots \ldots \ldots \ldots \ldots \ldots \ldots \ldots \ldots \ldots \ldots \ldots \ldots \ldots \ldots$

LIST OF FIGURES $\ldots \ldots \ldots \ldots \ldots \ldots \ldots \ldots \ldots \ldots \ldots \ldots \ldots \ldots \ldots \ldots$

LIST OF ACRONYMS $\ldots \ldots \ldots \ldots \ldots \ldots \ldots \ldots \ldots \ldots \ldots \ldots \ldots \ldots$

EXECUTIVE SUMMARY $\ldots \ldots \ldots \ldots \ldots \ldots \ldots \ldots \ldots \ldots \ldots \ldots \ldots \ldots$

1. INTRODUCTION

1.1 Formation of High-Level Waste and the Need to Reduce Volume $\ldots \ldots \ldots \ldots \ldots$

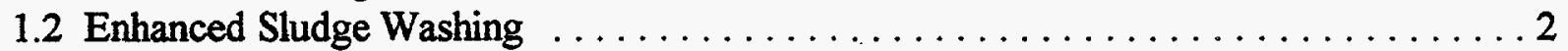

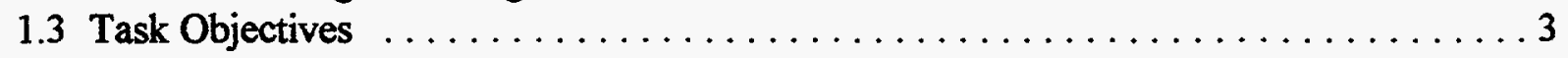

2. SLUDGE SAMPLES

2.1 Sludge Samples Tested $\ldots \ldots \ldots \ldots \ldots \ldots \ldots \ldots \ldots \ldots \ldots \ldots \ldots \ldots$

2.2 Types of Wastes in Hanford Tanks $\mathrm{S}-101$ and $\mathrm{C}-103 \ldots \ldots \ldots \ldots \ldots$

3. EXPERIMENTAL PROCEDURES

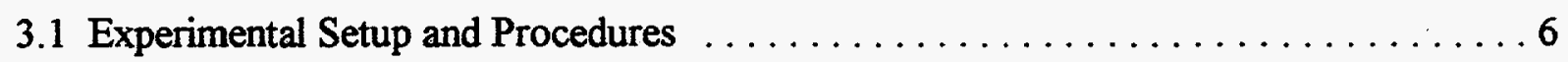

3.2 Water Washes and Caustic Leaches of Sludge from Tank S-101 . . . . . . . . . 12

3.3 Water Washes of Sludge from Hanford Tank C-103 . . . . . . . . . . . . . 18

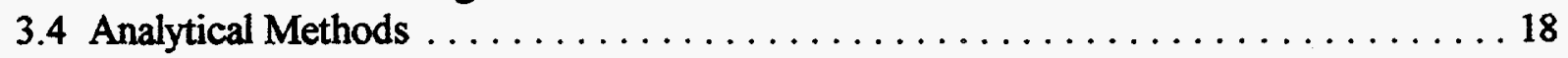

4. RESULTS AND DISCUSSION

4.1 Analysis: Initial Water Washes of Sludge from Tank S-101 . . . . . . . . . . . . 24

4.2 Analysis: Subsequent Leaches/Washes of Sludge from Tank S-101 . . . . . . . . 26

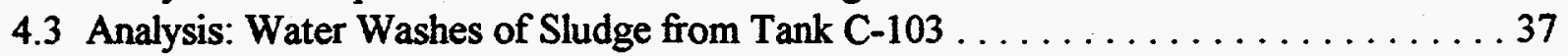

5. CONCLUSIONS AND RECOMMENDATIONS $\ldots \ldots \ldots \ldots \ldots \ldots \ldots \ldots$

6. ACKNOWLEDGMENTS $\ldots \ldots \ldots \ldots \ldots \ldots \ldots \ldots \ldots \ldots \ldots \ldots \ldots \ldots \ldots$

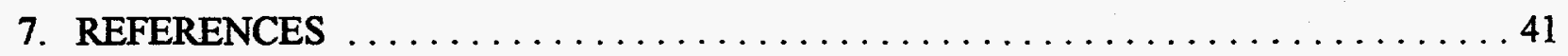





\section{LIST OF TABLES}

Table

Page

2.1 Hanford Tanks S-101 and C-103: Sludge Mass and Amounts of Key Constituents

3.1 Inhibited Water Washes of Sludge from Hanford Tank S-101

3.2 Wet and Dry Weights of Treated Sludge Samples from Tank S-101 and Conductance of the Caustic Leachates

3.3 Leaching Conditions for Each Aliquot of Washed Sludge from Hanford Tank S-101

3.4 Inhibited Water Washes of Sludge from Hanford Tank $\mathrm{C}-103 \ldots \ldots \ldots$

4.1 Effects of the Inhibited Water Washes on the Sludge from Hanford Tank S-101 . . . 25

4.2 Leach/wash and ESW Results for Key Components in the Sludge from

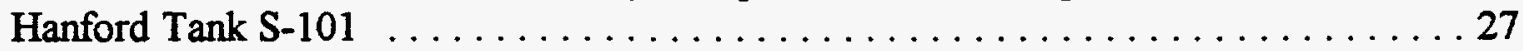

4.3 Concentrations of Key Components in the Leachates and in the Leached Solids from the Tank S-101 Sludge Sample 



\section{LIST OF FIGURES}

Figure

Page

3.1 Apparatus to Wash and Leach the Sludge Sample in the Fume Hood . . . . . . . . 8

3.2 Mixer System to Divide the Sludge Slurry into Aliquots $\ldots \ldots \ldots \ldots \ldots \ldots$

3.3 Tank S-101 Sludge: Wet Sludge Weights vs Conductance of the Wash Solutions . . . . 14

3.4 Tank S-101 Sludge: Wet Sludge Weights vs ${ }^{137}$ Cs Activity of the Wash Solutions . . . . . . . . . . . . . . . . . . . . . . . . . . 15

3.5 Tank C-103 Sludge: Wet Sludge Weights vs Conductance of the Wash Solutions ... . 21

3.6 Tank C-103 Sludge: Wet Sludge Weights vs ${ }^{137}$ Cs Activity of the Wash Solutions

4.1 Concentrations of Aluminum in the Leach Solutions . . . . . . . . . . . . . . . 33

4.2 Concentrations of Chromium in the Leach Solutions $\ldots \ldots \ldots \ldots \ldots \ldots \ldots$

4.3 Concentrations of Phosphate in the Leach Solutions $\ldots \ldots \ldots \ldots \ldots \ldots \ldots$ 



\section{LIST OF ACRONYMS}

CASD Chemical and Analytical Services Division

DOE Department of Energy

HLW High-Level Radioactive Waste

ICP-AES Inductively Coupled Plasma Atomic Emission Spectroscopy

ICP-MS Inductively Coupled Plasma Mass Spectrometry

LANL Los Alamos National Laboratory

LLW Low-Level Radioactive Waste

NMR Nuclear Magnetic Resonance

ORNL Oak Ridge National Laboratory

PNNL Pacific Northwest National Laboratory

RCF Relative Centrifugal Force

SRS Savannah River Site

SSTs Single-Shell Tanks

TFA Tank Focus Area

TRUs Transuranics

WHC Westinghouse Hanford Company 


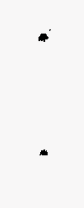




\section{EXECUTIVE SUMMARY}

In 1993, the Department of Energy (DOE) selected the enhanced sludge washing (ESW) process as the baseline for pretreatment of Hanford tank sludges. The ESW process uses a series of water washes and caustic leaches to separate nonradioactive components such as aluminum, chromium, and phosphate from the high-level waste sludges. If the ESW process is successful, the volume of immobilized high-level waste will be significantly reduced. Nearly all previous ESW tests have used process conditions that were designed to maximize the removal capabilities of the ESW process without regard to full-scale remediation considerations such as implications of secondary waste and available tank space. However, for a small portion of the Hanford sludges, the DOE has agreed to provide a private contractor with specified amounts of sludge, and the concentrations of key sludge components must be within certain ranges. Therefore, less aggressive caustic leaching may be adequate to meet the contract requirements.

The tests on the sludge from Hanford Tank S-101 focused on the effects of process variables such as sodium hydroxide concentration $(1$ and $3 \mathrm{M})$, temperature $\left(70\right.$ and $\left.95^{\circ} \mathrm{C}\right)$, and leaching time $(5,24,72$, and $168 \mathrm{~h})$ on the efficacy of the ESW process with realistic liquid-tosolid ratios. These results will eventually be used by the full-scale remediation effort to determine the appropriate ESW processing conditions after the feed specifications for the vitrifier have been determined. The initial water washes of the sludge from Tank S-101 were quite effective. Only $21 \%$ of the initial sludge mass remained after the sludge was washed and dried. Although $99 \%$ of the ${ }^{99} \mathrm{Tc}$ and $98 \%$ of the ${ }^{137} \mathrm{Cs}$ were transferred into the wash solutions, no ${ }^{60} \mathrm{Co},{ }^{90} \mathrm{Sr},{ }^{154} \mathrm{Eu},{ }^{155} \mathrm{Eu}$, ${ }^{241} \mathrm{Am},{ }^{244} \mathrm{Cm}$, plutonium, or uranium was detected in the water washes. After the washes were completed, only aluminum and chromium needed to be removed by the caustic leaches. While each combination of sodium hydroxide concentration and temperature could exceed the removal goal of $64 \%$ for chromium, the $3 \mathrm{M}$ sodium hydroxide leach at $70^{\circ} \mathrm{C}$ failed to meet the aluminum removal goal of $68 \%$ by $3 \%$. The leaches at $95^{\circ} \mathrm{C}$ were clearly more effective than those at $70^{\circ} \mathrm{C}$. Leaching time is another important processing variable needing to be considered because the aluminum and chromium concentrations increased significantly as the leaching times were increased. 
The test results with the sludge from Tank S-101 also demonstrated the complex chemistry involved in the ESW process. In 3 of the 16 tests, the dry weight of the leached/washed solids was greater than the dry weight of solids before they were leached. Since the caustic leaches should only affect aluminum, chromium, phosphate, silicon, and cesium, the new precipitatant(s) can be expected to be composed of combination(s) of these components plus sodium, hydroxides, and oxides. The most likely candidates for the new precipitants are sodium aluminosilicates. This speculation is supported by the preliminary results of an ESW study at the Pacific Northwest National Laboratory (PNNL) on sludge from Hanford Tank BX-112. A key difference between the ESW tests with sludge from Tanks S-101 and BX-112 is the ultimate fate of these aluminosilicates. The aluminosilicates in the PNNL tests could not be redissolved, while the aluminosilicates in this study could be dissolved with longer leaching times. This discrepancy should not be surprising since varicus forms of aluminosilicates were observed with tank waste simulants.

Another goal of this study was to evaluate the effectiveness of water washes on a sludge sample from Hanford Tank C-103. In sharp contrast to the washes with sludge from Tank S-101, the inhibited water washes with the sludge from Tank C-103 were not effective, so additional water washes after the retrieval process will not be beneficial. The inhibited water washes did not produce a significart decrease in the mass of the solids. The conductance results also indicate that this sludge sample contain very little water-soluble solids. Finally, very little radioactivity was removed from the solids by the washes.

The final objective of this study was to test potential process control monitors during the water washes and caustic leaches with actual sludge. Both ${ }^{137} \mathrm{Cs}$ activity and conductance were measured for each of the water washes and caustic leaches. Fewer difficulties were encountered with the conductance probe than with the gamma spectrometer, which was used to the ${ }^{137} \mathrm{Cs}$ activity. Nearly all of the changes in conductance values can be directly related to changes in the masses of the solids. Therefore, these results indicate that a conductance probe could serve as a useful process control monitor for the pretreatment of Hanford tank sludges. It should be noted that the aluminum industry currently uses conductance probes to control hot caustic leaches of bauxite. 


\section{INTRODUCTION}

\subsection{FORMATION OF HIGH-LEVEL WASTE AND THE NEED TO REDUCE VOLUME}

Through 1995, the chemical reprocessing of spent reactor fuel and irradiated targets had produced $215,300,000 \mathrm{~L}$ of solid high-level waste (HLW) and 158,100,000 L of liquid HLW (U.S. Department of Energy, 1996). Reprocessing of spent fuel produces an acidic liquid waste. At Hanford and the Savannah River Site (SRS), this liquid HLW was transferred to underground storage tanks and neutralized with sodium hydroxide to prevent corrosion of their carbon-steel tanks. The neutralization of the HLW formed hydrated oxides, which precipitated and created a layer of sludge. If the neutralized supernatant liquids were concentrated sufficiently by evaporation, sodium nitrite and sodium nitrate crystallized to form salt cakes. The radioactivity of $\mathrm{HLW}$ comes primarily from ${ }^{137} \mathrm{Cs}$ in the liquids/supernatants and ${ }^{90} \mathrm{Sr}$ in the solids/sludges. Most of the relatively small amount of transuranics (TRUs) can be found in the solids.

The Department of Energy (DOE) is required to treat and safely dispose of this HLW. It is expected that separation technologies will be used to divide the tank waste into HLW and lowlevel waste (LLW). At Hanford, the pretreatment or separation steps are expected to generate $78,700,000 \mathrm{~kg}$ of LLW and 4,300,000 kg of HLW (DeMuth, 1996). After these separation or pretreatment steps are completed, the segregated waste will be immobilized and geologically isolated. After the HLW has been concentrated at Hanford and the SRS, it will be incorporated into borosilicate glass, which will be sent to a geological repository for permanent disposal. The LLW will be immobilized in grout or glass and stored on site.

Technology development efforts have focused on reducing the volume of the HLW because the total costs associated with processing, immobilizing, and disposing of HLW and LLW are $\$ 2,126$ and $\$ 64$ per kilogram of waste oxide, respectively (DeMuth, 1996). The primary incentives to reduce the total volume of HLW glass include a lower overall life-cycle cost and the limited availability of repository space. 


\subsection{ENHANCED SLUDGE WASHING}

HLW volume can be reduced by various means, such as loading as much waste into the glass as possible. Technology development efforts are currently under way to improve glass formulations so that maximum waste loadings can be achieved. However, modifications to the glass formulations are expected to be only partially effective. Another approach is to separate the more abundant inert constituents, such as sodium and aluminum, from the radionuclides in the sludges. This process would also remove minor components such as chromium, sulfate, and phosphate, which can cause vitrification problems. In 1993, the DOE considered three separation options for the Hanford sludges. The treatment options (Jensen, 1994) included simple sludge washing, enhanced sludge washing, and advanced separations. Simple sludge washing uses only water or inhibited water, which contains $0.01 \mathrm{M}$ sodium nitrite and $0.01 \mathrm{M}$ sodium hydroxide. Enhanced sludge washing (ESW) refers to the simple sludge washing, which is followed by caustic leaching with 2-3 $M$ sodium hydroxide at an elevated temperature. The leached solids are then washed with the inhibited water to remove the dissolved components and any residual sodium hydroxide. Advanced separations consist of complete dissolution, if possible, followed by extensive radionuclide separation. An analysis of the options concluded that the simple sludge washing would result in an unreasonably large volume of immobilized HLW and that advanced separation would recuire extensive technology development and complex facilities. Therefore, ESW was selected as the baseline process to treat the Hanford sludges.

The ESW process is expected to solubilize the aluminum in the sludge by converting different forms of aluminum oxides to soluble sodium aluminate (Lumetta et al., 1996).

$$
\begin{array}{ll}
\text { Boehmite } & \mathrm{AlOOH}(\mathrm{s})+\mathrm{OH}^{-}(\mathrm{aq})+\mathrm{H}_{2} \mathrm{O} \rightarrow \mathrm{Al}(\mathrm{OH})_{4}^{-}(\mathrm{aq}) \\
\text { Gibbsite } & \mathrm{Al}(\mathrm{OH})_{3}(\mathrm{~s})+\mathrm{OH}^{-}(\mathrm{aq}) \rightarrow \mathrm{Al}(\mathrm{OH})_{4}^{-}(\mathrm{aq})
\end{array}
$$

Phosphate is typically present as insoluble phosphates and must be removed by the metathesis of water-insoluble metal phosphates into insoluble metal hydroxides and soluble phosphates such as sodium orthophosphate (Lumetta et al., 1996 and Lumetta et al., 1997). An example of this reaction is shown for iron phosphate in the following equation: 


$$
\mathrm{FePO}_{4}(\mathrm{~s})+3 \mathrm{NaOH}(\mathrm{aq}) \rightarrow \mathrm{Fe}(\mathrm{OH})_{3}(\mathrm{~s})+\mathrm{Na}_{3} \mathrm{PO}_{4}(\mathrm{aq})
$$

At room temperature, chromium may be converted to the soluble tetrahydroxochromium anion in $3 M$ sodium hydroxide. However, the chromium hydroxide oxide precipitates when such solutions are heated (Lumetta et al., 1996 and Lumetta et al., 1997).

$$
\begin{aligned}
& \mathrm{Cr}(\mathrm{OH})_{3}(\mathrm{~s})+\mathrm{NaOH}(\mathrm{aq}) \rightarrow \mathrm{Na}\left[\mathrm{Cr}(\mathrm{OH})_{4}\right](\mathrm{aq}) \\
& \mathrm{Na}\left[\mathrm{Cr}(\mathrm{OH})_{4}\right](\mathrm{aq})+\text { heat }-\mathrm{NaOH}(\mathrm{aq})+\mathrm{CrOOH}(\mathrm{s})+\mathrm{H}_{2} \mathrm{O}
\end{aligned}
$$

Relatively poor chromium dissolution was observed with some of the Hanford tank sludges. Therefore, researchers at PNNL continue to study the alkaline oxidative leaching of tank sludges (Rapko et al., 1997).

\subsection{TASK OBJECTIVES}

When the ESW process was chosen as the baseline technology for the pretreatment of Hanford tank sludges, several key assumptions, such as minimum wash and leach factors, were made with respect to the effectiveness of the ESW process. In order to verify these assumptions, single ESW tests, which used excessive amounts of inhibited water and caustic, were performed on sludge samples from 34 Hanford storage tanks by researchers at PNNL and Los Alamos National Laboratory (LANL). A research effort at Oak Ridge National Laboratory (ORNL) has measured the caustic dissolution behavior of sludge samples from several Hanford tanks under different conditions (Egan et al., 1998). At ORNL, the dissolution of aluminum, chromium, phosphate, and other sludge constituents in sodium hydroxide was evaluated using a wide range of sodium hydroxide concentrations $(3.8-6.33 \mathrm{M})$, temperatures $\left(50-93^{\circ} \mathrm{C}\right)$, volumes of caustic solution per unit mass of sludge (6.39-63.5 mL of sodium hydroxide/g of dry sludge), and leaching times (4-126 h). It should be noted that this ORNL study did not perform inhibited water washes prior to the caustic leachings.

As an extension of the earlier ORNL study, the primary objective of this ESW work on the sludge from Hanford Tank S-101 was to determine the effects of process variables such as 
sodium hydroxide concentration, temperature, and leaching time on the efficacy of the caustic leaching process under more realistic processing conditions. Another goal was to evaluate the effectiveness of water washes on a sludge sample from Hanford Tank C-103. The final objective of this study was to test potential process control monitors during the treatment of actual sludge.

\section{SLUDGE SAMPLES}

\subsection{SLUDGE SAMPLES TESTED}

Personnel at the Westinghouse Hanford Company (WHC) sent approximately $114 \mathrm{~g}$ of sludge from Hanford Tank S-101 to ORNL in March of 1997. The WHC 222-S laboratory number for this sample was S96T005965, and the jar number was 11720 . Approximately $3 \mathrm{~g}$ of the composite of Hanford Tank S-101 sludge was used by ORNL staff members during FY 1997 (Egan et al., 1997). Chemical and Analytical Services Division (CASD) personnel chemically analyzed approximately $1 \mathrm{~g}$ of the sludge as it was received. In addition, $1.90 \mathrm{~g}$ of Hanford Tank S-101 sludge was mixed with $21 \mathrm{~mL}$ of $3.99 \mathrm{M}$ sodium hydroxide for $65 \mathrm{~h}$ at $93^{\circ} \mathrm{C}$. The subsequent solids and liquid were also chemically analyzed. The results from all of these analyses were reported in detail earlier (Egan et al., 1997). The remainder of the sludge sample was used in the FY 1998 parametric studies on the ESW process.

In February 1998, an 89-g sludge sample from Hanford Tank C-103 was sent to ORNL from staff members of the Numantec Hanford Company. The WHC 222-S laboratory number for this sample was S97M000283, and the jar number was 13633. Approximately $1 \mathrm{~g}$ of the untreated sludge sample was set aside for future chemical analysis. The remainder of the sample was used in a series of water washes.

\subsection{TYPES OF WASTES IN HA.NFORD TANKS S-101 and C-103}

A PNNL study (Hill et al., 1995) used waste types and processing histories to qualitatively categorize the Hanford single-shell tanks (SSTs) into characteristic groups. It is expected that the 
wastes from tanks within a particular group are very similar in chemical content and physical characteristics. Hanford Tank S-101 belongs to Group I based on the Sort on Radioactive Waste Type (SORWT) model. The largest fraction of HLW in Tank S-101 is from the REDOX process, and this REDOX waste is most likely responsible for the sludge accumulation in these tanks. The second largest fraction of $\mathrm{HLW}$ is comprised of evaporator bottoms, which formed extremely hard salt cake. SORWT Group I consists of 22 SSTs, which contain 3,220,000 L of sludge and $5,440,000 \mathrm{~L}$ of salt cake. The values represent $11.6 \%$ of the total SST sludge volume and $36.9 \%$ of the total SST salt cake volume. For Tanks S-101 and C-103, the sludge mass and the amounts of key constituents such aluminum and ${ }^{137} \mathrm{Cs}$ are shown in Table 2.1 .

Tank C-103 belongs to SORWT Group XX. The only other tank in this group is Tank C-106. The primary waste type in this group is strontium-leached sludge; the next largest fraction of $\mathrm{HLW}$ is due to suspended particulates from the strontium washes of the PUREX wastes.

These suspended solids settled in the tanks, and they are believed to be a significant contributor to the solids characteristics and the high radioactivity. Tanks C-103 and C-106 contain no saltcake and $980,000 \mathrm{~L}$ of sludge, which is $2.1 \%$ of the total sludge volume. Tank C-103 is on the watch list as an "organic" tank because it has a separate layer of organic liquid.

Table 2.1. Hanford Tanks S-101 and C-103: sludge mass and amounts of key constituents

\begin{tabular}{cccccccc}
\hline $\begin{array}{c}\text { Hanford } \\
\text { tank }\end{array}$ & $\begin{array}{c}\text { Total mass } \\
(\mathrm{kg})\end{array}$ & $\begin{array}{c}\text { Aluminum } \\
\text { mass }(\mathrm{kg})\end{array}$ & $\begin{array}{c}\text { Chromium } \\
\text { mass }(\mathrm{kg})\end{array}$ & $\begin{array}{c}\text { Sodium } \\
\text { mass }(\mathrm{kg})\end{array}$ & $\begin{array}{c}\text { Phosphate } \\
\text { mass }(\mathrm{kg})\end{array}$ & $\begin{array}{c}{ }^{137} \mathrm{Cs} \text { activity } \\
(\mathrm{Bq})\end{array}$ & $\begin{array}{c}{ }^{90} \mathrm{Sr} \text { activity } \\
(\mathrm{Bq})\end{array}$ \\
\hline $\mathrm{S}-101^{\circ}$ & $2.67 \mathrm{E} 6$ & $2.37 \mathrm{E} 5$ & $1.39 \mathrm{E} 4$ & $5.09 \mathrm{E} 5$ & $1.18 \mathrm{E} 4$ & $1.32 \mathrm{E} 16$ & $5.96 \mathrm{E} 16$ \\
$\mathrm{C}-103^{b}$ & $3.14 \mathrm{E} 5$ & $4.56 \mathrm{E} 3$ & $1.94 \mathrm{E} 2$ & $1.49 \mathrm{E} 4$ & $3.94 \mathrm{E} 3$ & $6.92 \mathrm{E} 14$ & $3.15 \mathrm{E} 16$ \\
\hline
\end{tabular}

a(Colton, 1997).

${ }^{b}$ (Colton, 1995). 


\section{EX.PERIMENTAL PROCEDURES}

\subsection{EXPERIMENTAL SETUP AND PROCEDURES}

The sludge washing and caustic leaching procedures were performed in Building 4501 at ORNL. Due to the high radiation level, the first four or five washing steps were conducted in hot cell $\mathrm{A}$, and all subsequent inhibited water washes and the caustic leaches were conducted in a hot fume hood in laboratory 124. Before the experiments began, the hot cell and the fume hood were cleaned to minimize cross contamination. The contamination level in the cell is low enough to permit cell entry. Most of the equipment in the hot cell and fume hood were placed in large stainless steel trays to contain spills. Whenever possible, the controls for the equipment were positioned outside of the hot cell and fume hood.

A calibrated Mettler PM40150 top-loading balance, which has a capacity of $4000 \mathrm{~g}$ and a precision of $0.01 \mathrm{~g}$, was used in the hot cell to weigh the sludge sample, inhibited water, and centrifuge bottles. For the fume hood operations, samples were weighed with a calibrated Mettler PC4400 balance, which has a capacity of $4200 \mathrm{~g}$ and a precision of $0.01 \mathrm{~g}$, or a calibrated Mettler AE200, which has a capacity of $201 \mathrm{~g}$ and a precision of $0.0001 \mathrm{~g}$. After a sludge sample was received, nearly all of the sample was transferred from the Hanford laboratory 222-S jar directly into a preweighed $250-\mathrm{mL}$ widemouthed centrifuge bottle with the assistance of the first wash solution, which consisted of $0.01 M /$ sodium hydroxide and $0.01 M$ sodium nitrite. The centrifuge bottles were made of Nalgene ${ }^{\mathrm{TM}}$ polypropylene. After the sludge transfer, the bottle was reweighed, and the sample was then mixed, centrifuged, and decanted. In subsequent water washes, known amounts of inhibited water were added and mixed with the sludge sample from Tank S-101 or Tank C-103.

Three different devices were used to mix the sludge and the water wash. For the roomtemperature wash in the hot cell, a custom-designed rotator that turned the bottles end over end was used to mix the samples for $16-143 \mathrm{~h}$. For the $1-\mathrm{h}$ wash at $95^{\circ} \mathrm{C}$ in the hot cell, samples were placed into a furnace assembly, which was attached to a rocking mixer. The samples were rocked from $-45^{\circ}$ to $+45^{\circ}$ from the horizontal plane at a rate of approximately 8 cycles per 
minute. A more detailed description and a photograph of this furnace and rocker system is available elsewhere (Collins et al., 1997). As shown in Fig. 3.1, two new systems were designed and built to wash and leach the sludge samples in the hot fume hood. A VWR brand Series 400HPS hotplate/stirrer was used in the systems to heat and mix the samples. The sample holder for the hot plate/stirrer was made from a $17.8-\mathrm{cm} \times 17.8-\mathrm{cm} \times 6.9-\mathrm{cm}$ aluminum block and a $22.9-\mathrm{cm} \times 20.6-\mathrm{cm} \times 0.6-\mathrm{cm}$ aluminum plate. Two holes were drilled through the aluminum block. One hole, which has a diameter of $7.1 \mathrm{~cm}$, is in the center of the $17.8-\mathrm{cm} \times 17.8-\mathrm{cm}$ face, and the other hole, which has a diameter of $6.1 \mathrm{~cm}$, is in the corner of the $17.8-\mathrm{cm} \times 17.8-\mathrm{cm}$ face. Two thermocouple holes were also drilled into the aluminum block. The block was welded to the aluminum plate. Cylindrical holders, which fit into the center hole, were made for the $50-\mathrm{mL}$ centrifuge tubes and $250-\mathrm{mL}$ centrifuge bottles. These holders were made of stainless steel so the sample could be recovered if a centrifuge tube failed. The $250-\mathrm{mL}$ centrifuge bottle with the sludge to be washed was placed in the stainless steel holder, which was then inserted into the center hole. A $250-\mathrm{mL}$ centrifuge bottle containing ethylene glycol was placed in the corner. A thermocouple was placed in the ethylene glycol or the aluminum block, a second thermocouple was inserted next to the bottle with the sludge sample, and a third thermocouple was always inserted into the aluminum block. The first two thermocouples were monitored with an OMEGA temperature indicator, while the last thermocouple was connected to an OMEGA hightemperature controller (Model $\mathrm{CN}-375$ ) with a temperature indicator. The system was previously calibrated with a sludge simulant so the temperature of the liquid in the center hole could be set at 70 or $95^{\circ} \mathrm{C}$.

Upon completion of each wash or leach, the sample was centrifuged at $4500 \mathrm{rpm}$ for $20 \mathrm{~min}$ in an International Equipment Company Centra-GP8 tabletop centrifuge to separate the liquid from the solids. A four-place swinging bucket rotor (Model 3218) was used. The $g$ forces for the $50-\mathrm{mL}$ centrifuge tubes and $250-\mathrm{mL}$ centrifuge bottles were approximately 4300 and 4500 , respectively. It should be noted that the stir bar, which was used to mix the sludge sample in the hot fume hood, was removed with a magnet before the sample was centrifuged. After the sample was centrifuged, the liquid was decanted into a preweighed centrifuged tube. The conductance of each wash solution was measured with a YSI model 32 conductance meter. 


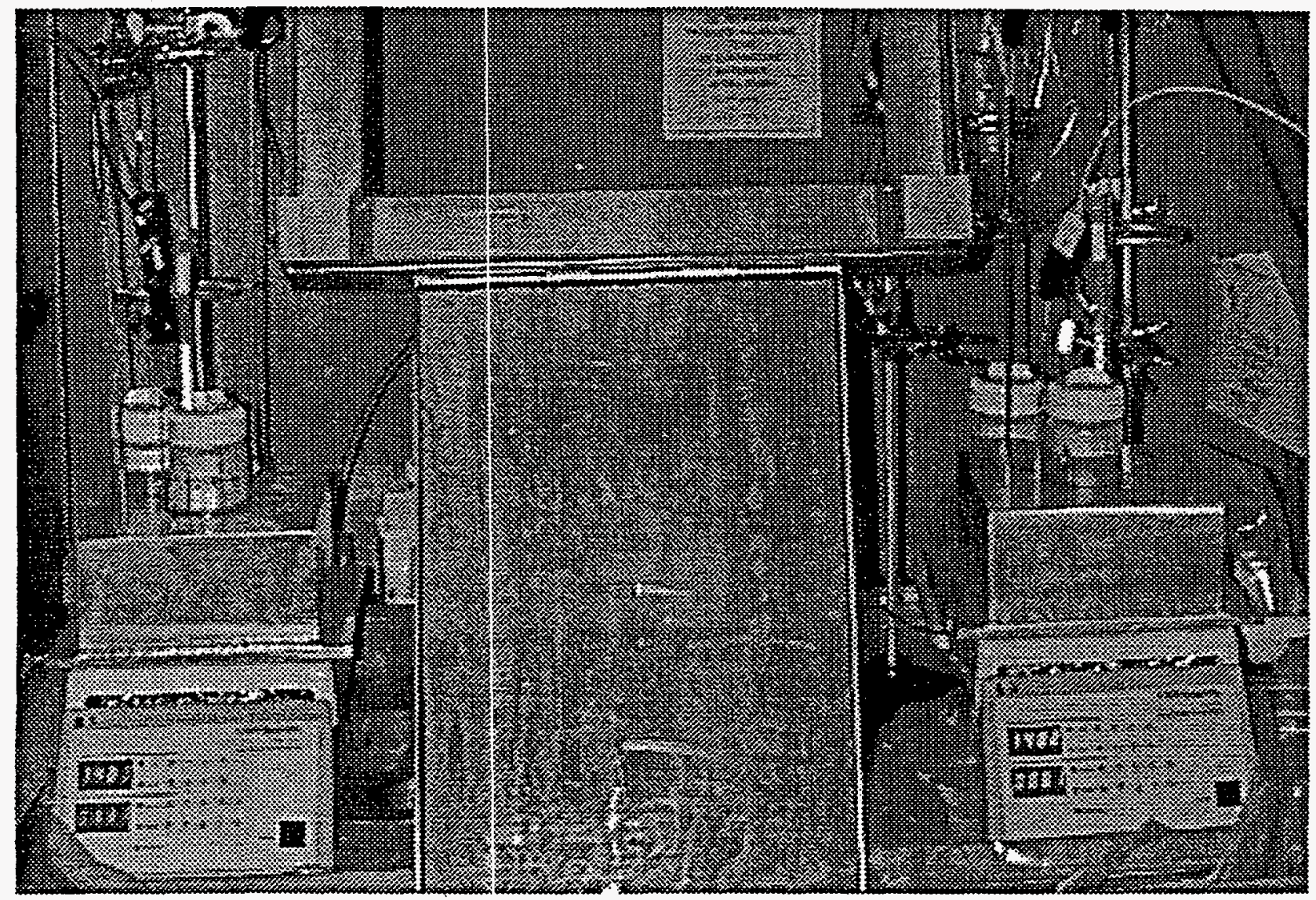

Fig. 3.1. Apparatus to wa:sh and leach the sludge samples in the fume hood. 
The ${ }^{137} \mathrm{Cs}$ level was determined with a Canberra Genie-2000 ${ }^{\mathrm{TM}}$ spectroscopy system and a highpurity germanium coaxial detector (Model CPHDS30-18190) from Oxford Instruments, Inc.

After the initial water washes had removed all water-soluble solids, the sludge was slurried with a known amount of inhibited water and transferred into a custom-designed mixer system, as shown in Fig. 3.2. The sample container and its top are made of stainless steel and Plexiglas, respectively. The sample container can hold approximately $220 \mathrm{~mL}$ of slurry. The mixer consists of a motor from Palo Laboratory Supplies, a 7-in. shaft, and a 4-blade propeller, which has an overall diameter of 2 in. The shaft and propeller are made of stainless steel. A slit was cut in the Plexiglas cover for the shaft of the mixer so the cover could be utilized during the mixing operation. The speed of the motor is controlled with a Variac variable transformer. A tube with a stainless steel valve for sampling the sludge slurry was located at the bottom of the sample container. The section of tube above the valve was made as short as possible to prevent sludge solids from collecting there and resisting suspension during mixing. The volume of this section of tube is approximately $2 \mathrm{~mL}$.

The amount of slurry to be transferred to a $30-$ or $50-\mathrm{mL}$ centrifuge tube was estimated based on the total weight of the slurry. After the desired weight of the slurry for a particular tube was determined, the same weight of water was added to the tube, and the water level was marked. After the tube was marked, the water was removed, and the tube was dried and weighed. While the sludge slurry was being mixed, each sample tube was filled to the line on the tube with the slurry. Then the valve was closed, and the centrifuge tube was sealed with a cap. This process continued until all of the drainable sludge slurry was transferred. The samples were then centrifuged, and the liquid was decanted into preweighed centrifuge tubes, which were weighed again after the transfer. Most of the sludge samples were then used in the caustic leaches. One sample of washed sludge was sent to the CASD for chemical analysis. In order to determine the water content of the washed solids, another sample was placed in a gravity convection oven from Precision and heated at temperatures of up to $104^{\circ} \mathrm{C}$ until the sample reached a constant weight.

The same apparatus used to wash the sludge in the fume hood was used to leach the individual washed sludge samples. The sludge samples in the $30-\mathrm{mL}$ centrifuge tubes were 


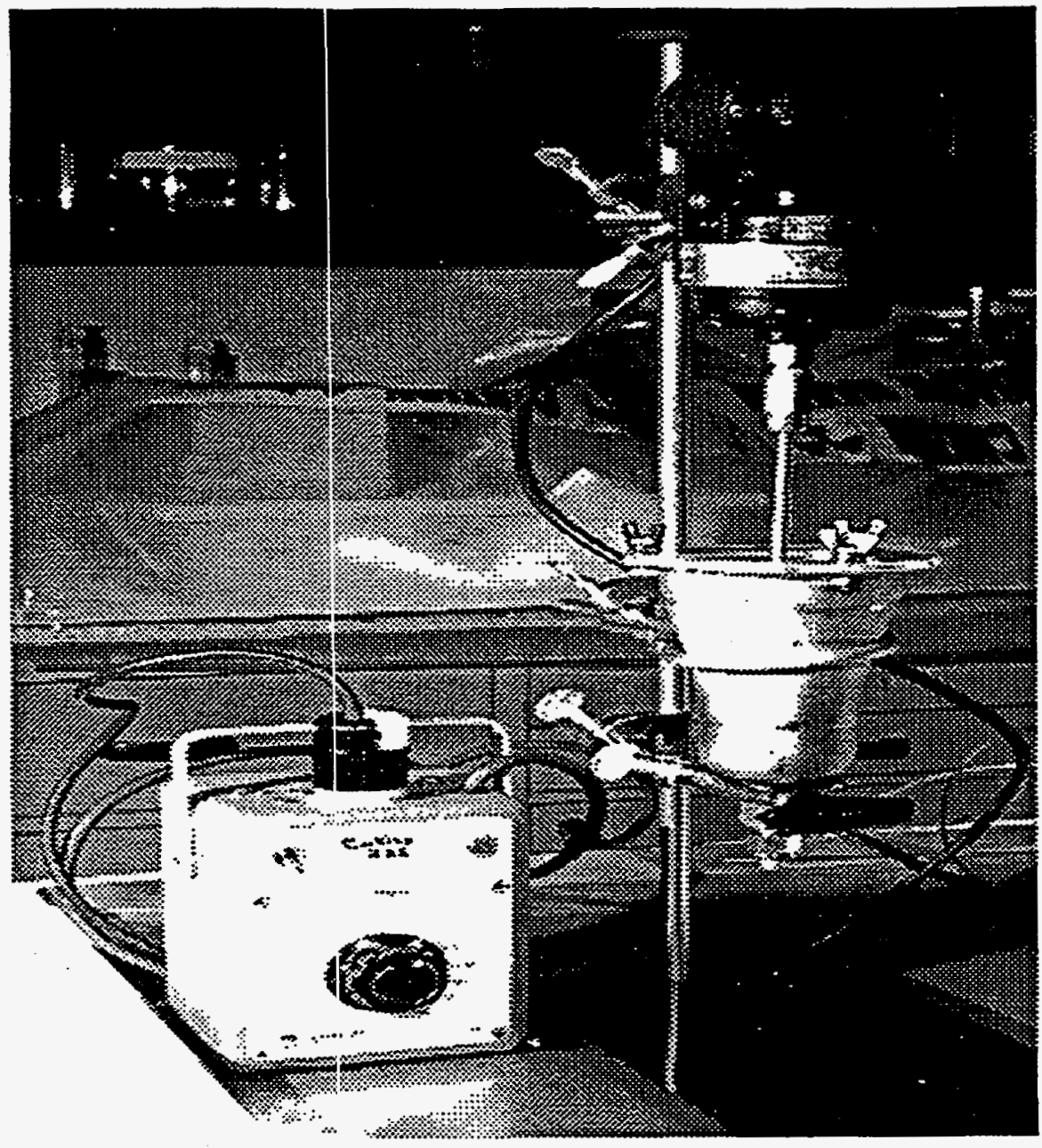

Fig 3.2. Mixer system to divide sludge slurry into aliquots. 
transferred to $250-\mathrm{mL}$ centrifuge tubes with a predetermined volume of sodium hydroxide, which was also used to leach the sludge samples. The volume of sodium hydroxide was based on equilibrium calculations by the Tank Focus Area (TFA) task on the prevention of solids formation. A Thermolyne Maxi-mix $\mathrm{II}^{\mathrm{TM}}$. vortex mixer was used to suspend the sludge samples. The weights of the bottles before and after the transfers were recorded. A preweighed magnetic stir bar was added to each sample to be leached. Then, the liquid level was marked on each centrifuge bottle. The original lid with the centrifuge tube was replaced with a preweighed lid with a small hole. A 4-mL polyethylene transfer pipette, which served as a condenser, was placed in the hole. A slit was cut in the bulb of the pipette, and a Rainin pipette filter was inserted into the bulb. The aluminum block was preheated to the desired temperature, and the sample to be leached was placed in the center of the block. The temperature of the leach solution and the liquid level were checked periodically. Since a noticeable amount of evaporation would occur during the tests, known amounts of distilled water were periodically added to maintain the volume of sample.

At the conclusion of each leaching procedure, mixing of the sludge was discontinued, and the condenser and the lid with the hole for the transfer pipette were removed and weighed. The stir bar was removed with the aid of a magnet and weighed. The centrifuge tube with its original lid was weighed and centrifuged for $3.5 \mathrm{~min}$ at $3500 \mathrm{rpm}$. The sample holder for the centrifuge was preheated to 70 or $95^{\circ} \mathrm{C}$. After the sample was centrifuged, the liquid was immediately decanted into a preweighed and preheated centrifuge tube. Tests with simulants indicated that the temperature of the decanted liquid was $5-10^{\circ} \mathrm{C}$ lower than the leach temperature. The liquid sample was then placed into a preheated ethylene glycol bath, and temperature of the bath corresponded to the leach temperature. The bath consisted of a Lab-Line Pyro-Magnestir Model 1266, a thermometer, two perforated Teflon disks, and a 2-L beaker. After the decanted liquid was in the ethylene glycol bath for a minimum for $30 \mathrm{~min}$, a portion of the hot leach solution was filtered and transferred into a preweighed analytical bottle. Syringes from Becton Dickinson, Nalgene-nylon-membrane $0.45-\mu \mathrm{m}$-porosity syringe filters, and a small piece of Tygon tubing from Norton Company were used to filter the solution. Prior to the filtration, the syringes, filters, and tubing were weighed and then heated to 70 or $95^{\circ} \mathrm{C}$. The filtered and unfiltered leach 
solutions were allowed to cool to room temperature. Then, a portion of the filtered leach solution was transferred into a 10 - or $25-\mathrm{mL}$ volumetric flask and weighed in order to determine the specific gravity of the leach solution. The leach solution in the volumetric flask was returned to the analytical bottle, which was sent to CASD for chemical analysis. The used syringes, filters, tubing, and volumetric flask were weighed in order to determine the amount of leach solution that was lost during the filtration and specific gravity measurement.

After the leached solids were centrifuged for $20 \mathrm{~min}$ at $4500 \mathrm{rpm}$, the liquid was decanted, and the solids were weighed. The solids were washed three times with $25 \mathrm{~mL}$ of inhibited water. The sample was then placed on a vortex mixer until all of the solids were suspended in the solution. After the sample was weighed, it was then centrifuged for $5 \mathrm{~min}$ at $4500 \mathrm{rpm}$, and the liquid was decanted into a preweighed centrifuge tube. This procedure was repeated two more times with one exception. After the last wash, the sample was centrifuged for $20 \mathrm{~min}$ at $4500 \mathrm{rpm}$. The weights of the solits and the combined water washes were determined. A portion of the washed solids were dried unili a constant weight was achieved. In the 168-h tests, the wash solutions were filtered with $0.45-\mu \mathrm{m}$-porosity syringe filters, and the specific gravity of the filtered wash solution was determiried with a volumetric flask. The remaining solids and filtered wash solutions from the 168 -h test: were sent to CASD for chemical analysis.

\subsection{WATER WASHES AND CA.USTIC LEACHES OF SLUDGE FROM TANK S-101}

At the start of the inhibited water washes of the sludge from Hanford Tank S-101, a $110.61-\mathrm{g}$ sludge sample was transferred to a $250-\mathrm{mL}$ centrifuge bottle with the assistance of the first wash solution. The experimental conditions for the six water washes of the Tank S-101 sludge sample are shown in Table 3.1. After the leach slurry was centrifuged at the specified Relative Centrifugal Force (RCF), the liquid was decanted, and the wet solids were then weighed. The results of these stepss are also included in Table 3.1. The conductance and ${ }^{137} \mathrm{Cs}$ activity of each of these wash solutions are provided in Table 3.1 and in Figs. 3.3 and 3.4. The ${ }^{137} \mathrm{Cs}$ results were normalized based on the activity of the composite wash solution, which was counted by Chemical Technology Ilivision and CASD staff. 
Table 3.1. Inhibited water washes of sludge from Hanford Tank S-101

\begin{tabular}{|c|c|c|c|c|c|c|c|c|c|}
\hline Wash & Temp. & Time & $\begin{array}{l}\text { Wt of } \mathrm{H}_{2} \mathrm{O} \\
\text { added }(\mathrm{g})\end{array}$ & $\begin{array}{l}\text { Type of } \\
\text { mixing }\end{array}$ & $\begin{array}{l}\text { RCF } \\
(\times g)\end{array}$ & $\begin{array}{l}\text { Wt of wet } \\
\text { solids (g) }\end{array}$ & $\begin{array}{c}{ }^{137} \mathrm{Cs} \text { in } \\
\text { wash }(\mathrm{Bq})\end{array}$ & $\begin{array}{l}\text { Total }{ }^{137} \mathrm{Cs} \\
\text { removal (\%) }\end{array}$ & $\begin{array}{c}\text { Conductance } \\
(\mathrm{m} U)\end{array}$ \\
\hline 1 & $\begin{array}{l}\text { Room } \\
\text { Temp. }\end{array}$ & $24 \mathrm{~h}$ & 102.98 & $\begin{array}{l}\text { End over } \\
\text { end }\end{array}$ & 4500 & 91.58 & $2.96 \mathrm{E} 8$ & 62.2 & 625 \\
\hline 2 & $\begin{array}{l}\text { Room } \\
\text { Temp. }\end{array}$ & $16 \mathrm{~h}$ & 102.28 & $\begin{array}{l}\text { End over } \\
\text { end }\end{array}$ & 4500 & 83.09 & $1.19 \mathrm{E} 8$ & 87.1 & 274 \\
\hline 3 & $\begin{array}{l}\text { Room } \\
\text { Temp. }\end{array}$ & $143 \mathrm{~h}$ & 100.43 & $\begin{array}{l}\text { End over } \\
\text { end }\end{array}$ & 4500 & 78.85 & $2.69 \mathrm{E} 7$ & 92.6 & 122 \\
\hline 4 & $\begin{array}{l}\text { Room } \\
\text { Temp. }\end{array}$ & $21 \mathrm{~h}$ & 103.21 & $\begin{array}{l}\text { End over } \\
\text { end }\end{array}$ & 4500 & 75.04 & $1.13 E 7$ & 95.0 & 55 \\
\hline 5 & $97^{\circ} \mathrm{C}$ & $\begin{array}{l}1 \mathrm{~h} \\
\text { plus }\end{array}$ & 120.73 & Rocked & 4500 & 68.20 & $7.29 \mathrm{E} 6$ & 96.5 & 26 \\
\hline 6 & $97^{\circ} \mathrm{C}$ & $\begin{array}{l}1 \mathrm{~h} \\
\text { plus }\end{array}$ & 119.10 & $\begin{array}{c}\text { Magnetic } \\
\text { stir bar }\end{array}$ & 4500 & 66.78 & $4.75 \mathrm{E} 6$ & 97.6 & 17 \\
\hline
\end{tabular}




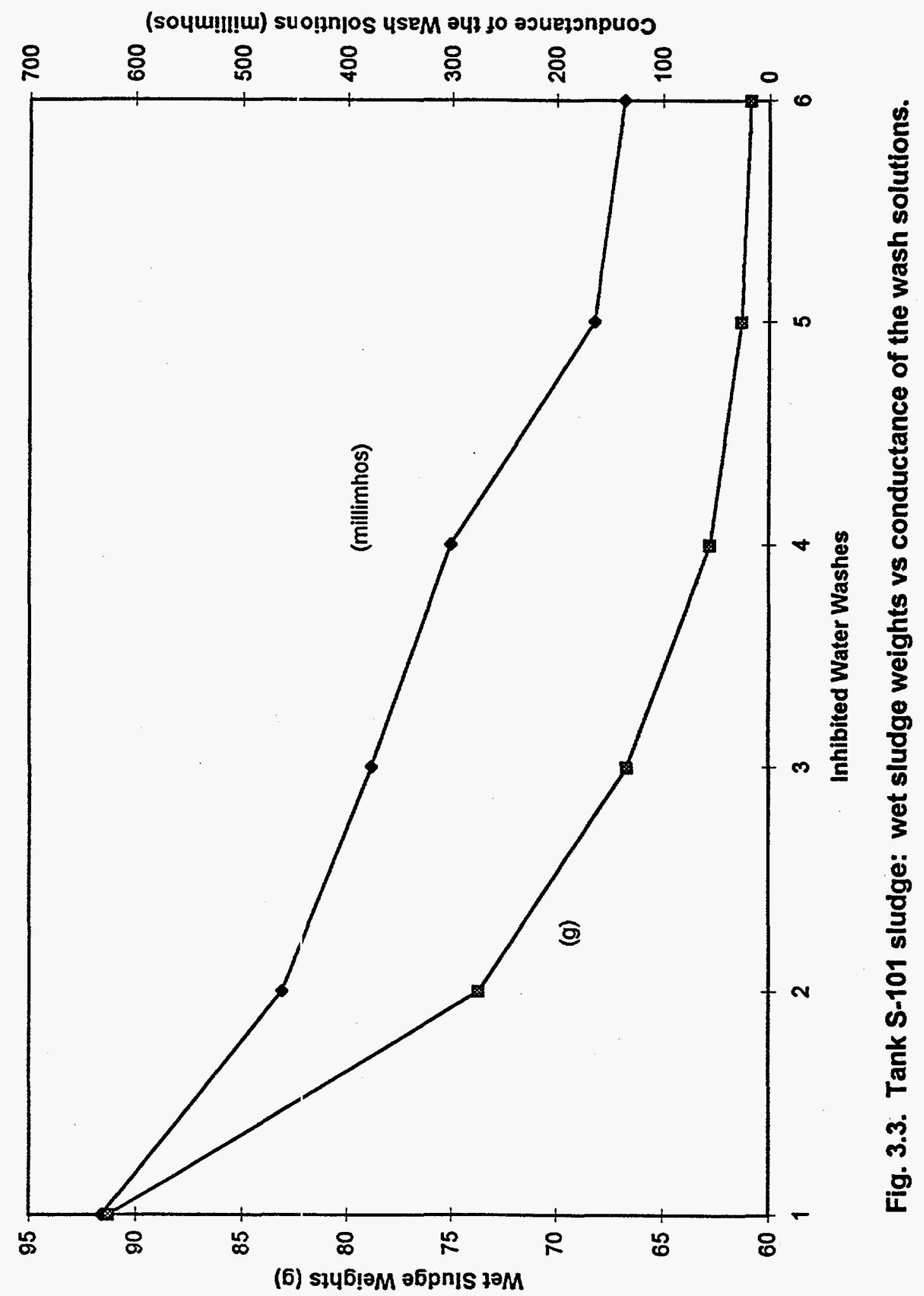




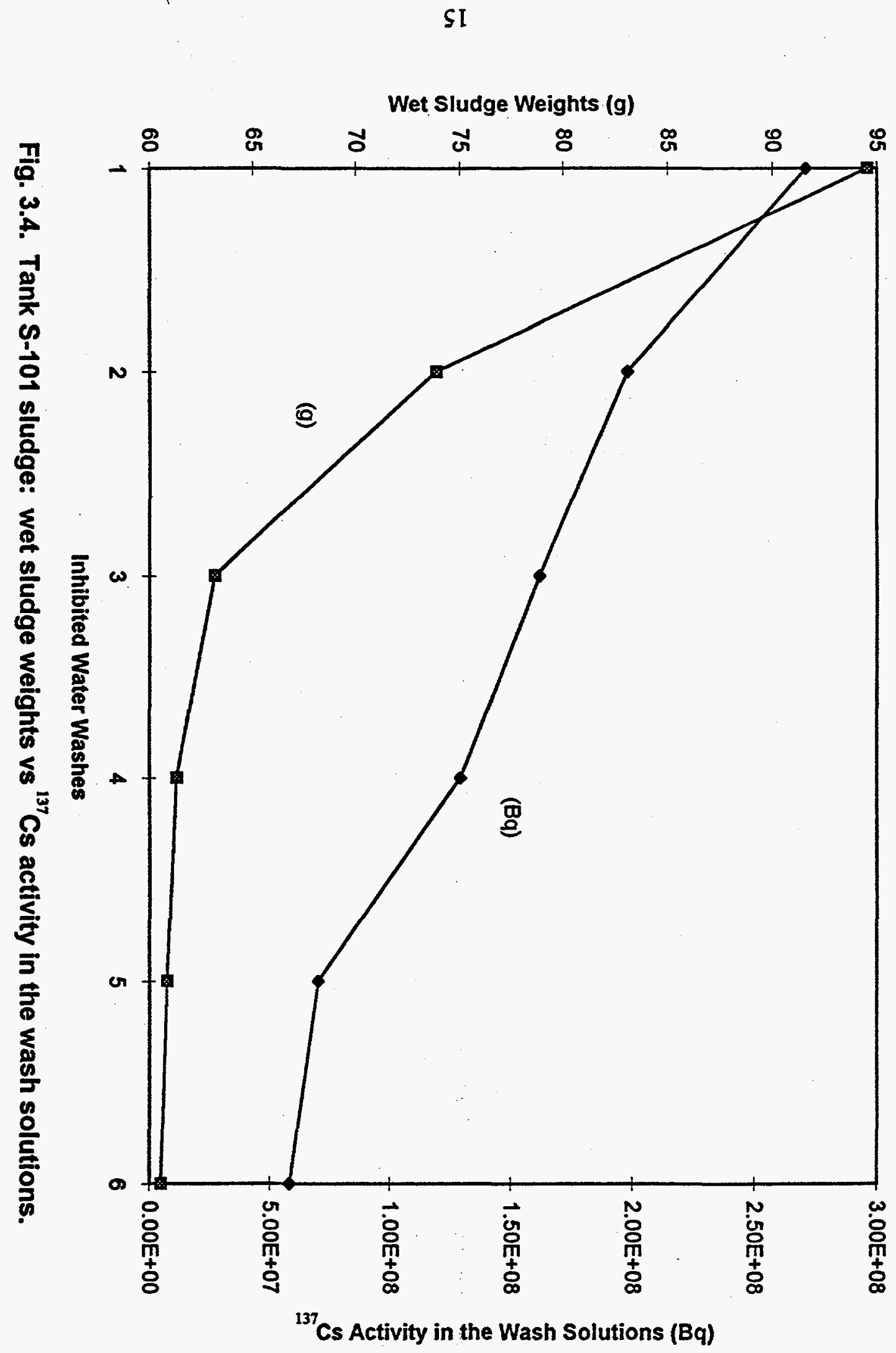


After these results indicated that any further water washes would be ineffective, an inhibited water wash was used to transfer the washed sludge into the mixer system. While the slurry was being mixed, 20 homogeneous samples were transferred into preweighed centrifuge tubes. Each tube was centrifuged, and the liquid was decanted. The weights of the washed sludge samples and the decanted liquids were measured and recorded. Most of the washed sludge in one of the centrifuge tubes was 1ransferred to a preweighed crucible. After the transfer, the initial weight of the washed sludge in the crucible was $0.9245 \mathrm{~g}$. The crucible was then heated at $76^{\circ} \mathrm{C}$ for $1 \mathrm{~h}$, at $97^{\circ} \mathrm{C}$ for $0.5 \mathrm{~h}$, and then at $104^{\circ} \mathrm{C}$ until the dried sludge reached a constant weight. Before the dried sludge could be weighed, the hot crucible was placed in a desiccator until the sample had cooled to ambient temperature. The final weight of the dried sludge was $0.2516 \mathrm{~g}$. Therefore, the water content in this sample of washed sludge was $72.8 \%$. It was assumed that the each aliquot of washed sludge would contain the same percentage of water. Therefore, this result was used to estimate the dry weight of each of the washed sludge samples, as shown in Table 3.2. After the final weighing of the dried sludge, the sample was exposed to

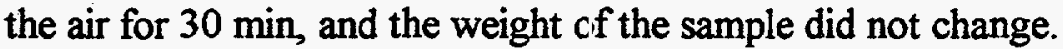

The decanted liquids from the final transfer step were combined into a single 250-mL centrifuge tube. Then $10 \%$ of the decanted liquid from each of the wash steps and the transfer wash was removed in order to make a composite wash solution. A total of $85.60 \mathrm{~g}$ of decanted liquid was placed into a single centrifuge tube. The composite wash solution was then mixed with the vortex mixer. Subsequently, a $50-\mathrm{mL}$ sample of the composite wash solution was filtered with $0.45-\mu \mathrm{m}$-porosity syringe filters. This filtration step is a precaution to ensure that only substances dissolved into wash solution would be analyzed by CASD. The weight of $25 \mathrm{~mL}$ of the filtered composite wash solution was $26.04 .3 \mathrm{~g}$. In addition, a $1.867 \mathrm{~g}$ sample of washed sludge was also sent to CASD for chemical analysis.

The density of the composite wash solution and the dry weight of the washed sludge sample were used to determine that the original sludge sample contained $33.40 \mathrm{~g}$ or $30 \mathrm{wt} \%$ water-soluble solids, $23.17 \mathrm{~g}$ or $21 \mathrm{wt} \%$ water-insoluble solids, and $54.04 \mathrm{~g}$ or $49 \mathrm{wt} \%$ water. An earlier test at PNNL determineci that its sludge sample from Hanford Tank S-101 contained 
Table 3.2. Wet and dry weights of treated sludge samples from Tank S-101 and conductance of the caustic leachates

\begin{tabular}{lccccc}
\hline \multicolumn{1}{c}{ Sample ID } & $\begin{array}{c}\text { Washed solids } \\
\text { wet wt }(\mathrm{g})\end{array}$ & $\begin{array}{c}\text { Washed solids } \\
\text { dried wt (g) }\end{array}$ & $\begin{array}{c}\text { Leached/washed } \\
\text { solids wet wt (g) }\end{array}$ & $\begin{array}{c}\text { Leached/washed } \\
\text { solids dried wt (g) }\end{array}$ & $\begin{array}{c}\text { Conductance of } \\
\text { leachates (mJ) }\end{array}$ \\
\hline S101-1-70-5 & 4.524 & 1.231 & 5.7226 & 1.292 & 69.0 \\
S101-1-70-24 & 4.537 & 1.236 & 4.9070 & $b$ & 69.8 \\
S101-1-70-72 & 4.605 & 1.254 & 3.8291 & 1.069 & 69.3 \\
S101-1-70-168 & 4.980 & 1.356 & 3.8088 & 1.015 & 66.1 \\
S101-1-95-5 & 4.655 & 1.267 & 3.9683 & & \\
S101-1-95-24 & 4.692 & 1.277 & 2.9201 & 1.067 & 62.1 \\
S101-1-95-72 & 4.730 & 1.288 & 2.6568 & 0.931 & 65.8 \\
S101-1-95-168 & 5.082 & 1.384 & 2.3027 & 0.842 & 65.4 \\
& & & & & 64.8 \\
S101-3-70-5 & 4.747 & 1.292 & 5.9276 & 1.441 & 96.4 \\
S101-3-70-24 & 4.771 & 1.299 & 5.8252 & 1.440 & 106.8 \\
S101-3-70-72 & 4.956 & 1.350 & 4.7479 & 1.309 & 102.5 \\
S101-3-70-168 & 6.827 & 1.859 & 5.6212 & 1.311 & 89.0 \\
& & & & & \\
S101-3-95-5 & 4.368 & 1.189 & 2.8221 & 0.974 & 98.8 \\
S101-3-95-24 & 4.439 & 1.209 & 1.8978 & 0.801 & 81.5 \\
S101-3-95-72 & 4.786 & 1.302 & 1.8344 & 0.774 & 71.8 \\
S101-3-95-168 & 4.996 & 1.359 & 1.4312 & 0.576 & 69.0 \\
\hline
\end{tabular}

${ }^{a}$ Sample numbering convention: Hanford tank-sodium hydroxide concentration-leaching temperature-leaching temperature.

${ }^{b}$ An error during the drying procedure is suspected. The actual dried weight is probably between 1.20 and $1.25 \mathrm{~g}$. 
$42 \mathrm{wt} \%$ water-soluble solids, 22 vt \% water-insoluble solids, and $36 \mathrm{wt} \%$ water (Lumetta et al., 1997). Some differences can be expected since the tank waste is not homogeneous.

Table 3.3 summarizes the leaching conditions for each aliquot of the washed sludge from Hanford Tank S-101. Equilibrium calculations by the TFA task entitled Sludge Treatment Studies were used to determine the amount of sodium hydroxide to be used in each test. The amounts of sodium, nitrate, hydroxide, aluminate, and aluminum hydroxide after each processing step were calculated. The results for the four leach conditions were as follows: (1) $20.0 \mathrm{~mL}$ of sodium hydroxide per gram of initial sludge solids with $1 \mathrm{M}$ sodium hydroxide at $70^{\circ} \mathrm{C}$, (2) 9.9 $\mathrm{mL}$ of sodium hydroxide per gram of initial sludge solids with $1 \mathrm{M}$ sodium hydroxide at $100^{\circ} \mathrm{C}$, (3) $3.0 \mathrm{~mL}$ of sodium hydroxide per gram of initial sludge solids with $3 M$ sodium hydroxide at $70^{\circ} \mathrm{C}$, and (4) $5.7 \mathrm{~mL}$ of sodium hydroxide per gram of initial sludge solids with $3 \mathrm{M}$ sodium hydroxide at $100^{\circ} \mathrm{C}$. The calculated amounts of sodium hydroxide were increased by $50 \%$ in the actual experiments to account for uncertainties associated with the calculations.

\subsection{WATER WASHES OF SLUDGE FROM HANFORD TANK C-103}

After a 1.85-g sample of the sludge from Hanford Tank C-103 was removed for analysis, the remainder of the sludge, which weighed $83.19 \mathrm{~g}$, was transferred to a $250-\mathrm{mL}$ centrifuge bottle with the assistance of the first wash solution. The sludge sample from Tank C-103 was washed, centrifuged, and weighed. The conductance and ${ }^{137} \mathrm{Cs}$ activity of the decanted wash solutions were measured. The sludge from Tank C-103 was washed a total of four times. The experimental conditions of these water washes are shown in Table 3.4. The wet weights of the centrifuged solids as well as the conductance and ${ }^{137} \mathrm{Cs}$ activity of the decanted wash solutions are also provided in Table 3.4 and in Figs. 3.5 and 3.6.

\subsection{ANALYTICAL METHODS}

Analytical methods that were used by the CASD personnel for this study were similar to those described in a recent ORNL report (Keller et al., 1996). Samples of sludge solids were 
Table 3.3. Leaching conditions for each aliquot of washed sludge from Hanford Tank S-101

\begin{tabular}{lccccc}
\hline Sample ID & $\begin{array}{c}\mathrm{NaOH}] \\
(M)\end{array}$ & $\begin{array}{c}\text { Leach temp } \\
\left({ }^{\circ} \mathrm{C}\right)\end{array}$ & $\begin{array}{c}\text { Leach time } \\
(\mathrm{h})\end{array}$ & $\begin{array}{c}\mathrm{NaOH} \text { added } \\
(\mathrm{g})\end{array}$ & $\begin{array}{c}\text { Liquid: initial } \\
\text { solids }(\mathrm{mL} / \mathrm{g})\end{array}$ \\
\hline S101-1-70-5 & 1 & 70 & 5 & 175.37 & 30.0 \\
S101-1-70-24 & 1 & 70 & 24 & 176.00 & 30.0 \\
S101-1-70-72 & 1 & 70 & 72 & 178.32 & 30.0 \\
S101-1-70-168 & 1 & 70 & 168 & 193.08 & 30.0 \\
& & & & & \\
S101-1-95-5 & 1 & 95 & 5 & 89.53 & 14.9 \\
S101-1-95-24 & 1 & 95 & 24 & 90.01 & 14.9 \\
S101-1-95-72 & 1 & 95 & 72 & 90.81 & 14.9 \\
S101-1-95-168 & 1 & 95 & 168 & 97.40 & 14.9 \\
& & & & & \\
S101-3-70-5 & 3 & 70 & 5 & 56.09 & 8.5 \\
S101-3-70-24 & 3 & 70 & 24 & 56.23 & 8.5 \\
S101-3-70-72 & 3 & 70 & 72 & 58.50 & 8.5 \\
S101-3-70-168 & 3 & 70 & 168 & 80.28 & 8.5 \\
& & & & & \\
S101-3-95-5 & 3 & 95 & 5 & 27.40 & 4.5 \\
S101-3-95-24 & 3 & 95 & 24 & 27.86 & 4.5 \\
S101-3-95-72 & 3 & 95 & 72 & 29.84 & 4.5 \\
S101-3-95-168 & 3 & 95 & 168 & 31.35 & 4.5 \\
& & & & & \\
\hline
\end{tabular}

aSample numbering convention: Hanford tank-sodium hydroxide concentration-leaching temperature-leaching temperature. 
Table 3.4. Inhibited water washes of sludge from Hanford Tank C-103

\begin{tabular}{ccccccccc}
\hline Wash & Temp. & $\begin{array}{c}\text { Time } \\
(\mathrm{h})\end{array}$ & $\begin{array}{c}\mathrm{Wt} \text { of } \mathrm{H}_{2} \mathrm{O} \\
\text { added }(\mathrm{g})\end{array}$ & $\begin{array}{c}\text { Type of } \\
\text { mixing }\end{array}$ & $\begin{array}{c}\mathrm{RCF} \\
(\mathrm{x} \mathrm{g})\end{array}$ & $\begin{array}{c}\text { Wt of wet } \\
\text { solids (g) }\end{array}$ & $\begin{array}{c}{ }^{137} \mathrm{Cs} \text { in } \\
\text { wash (Bq) }\end{array}$ & $\begin{array}{c}\text { Conductance } \\
(\mathrm{m})\end{array}$ \\
\hline 1 & $\begin{array}{l}\text { Room } \\
\text { temp. }\end{array}$ & 143 & 120.95 & $\begin{array}{c}\text { End over } \\
\text { end }\end{array}$ & 4500 & 90.54 & $2.66 \mathrm{E} 7$ & 57.5 \\
2 & $\begin{array}{l}\text { Room } \\
\text { temp. }\end{array}$ & 22 & 116.78 & $\begin{array}{c}\text { End over } \\
\text { end }\end{array}$ & 4500 & 85.84 & $9.40 \mathrm{E} 6$ & 20.5 \\
3 & $\begin{array}{l}\text { Room } \\
\text { temp. }\end{array}$ & 29 & 126.70 & $\begin{array}{c}\text { End over } \\
\text { end }\end{array}$ & 4500 & 84.00 & $1.12 \mathrm{E} 7$ & 9.1 \\
4 & $97^{\circ} \mathrm{C}$ & 2 & 113.11 & Rocked & 4500 & 80.66 & $6.92 \mathrm{E} 6$ & 7.4 \\
\hline
\end{tabular}




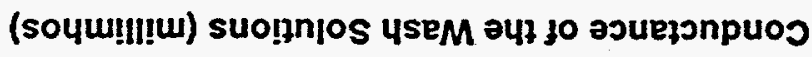

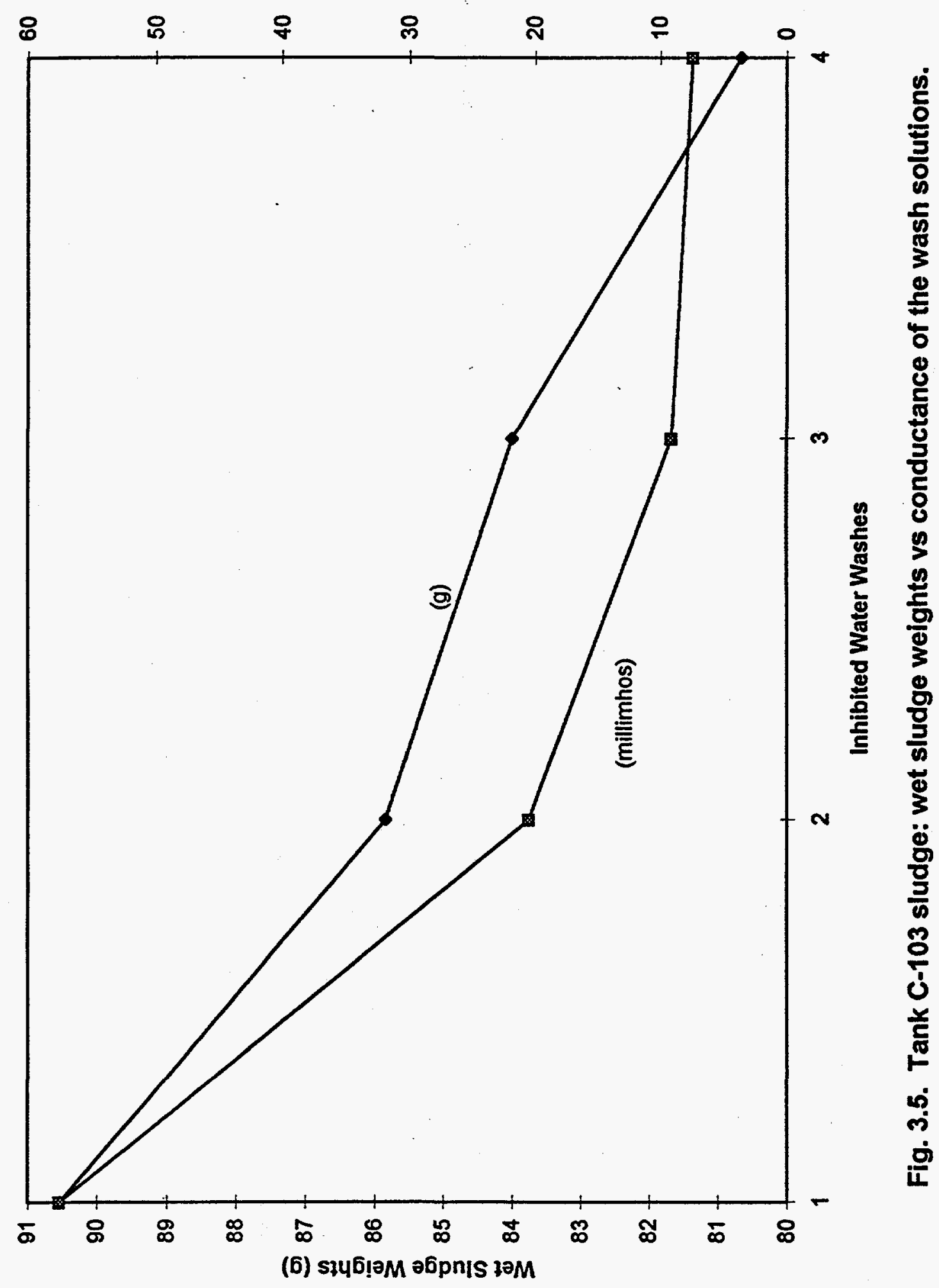




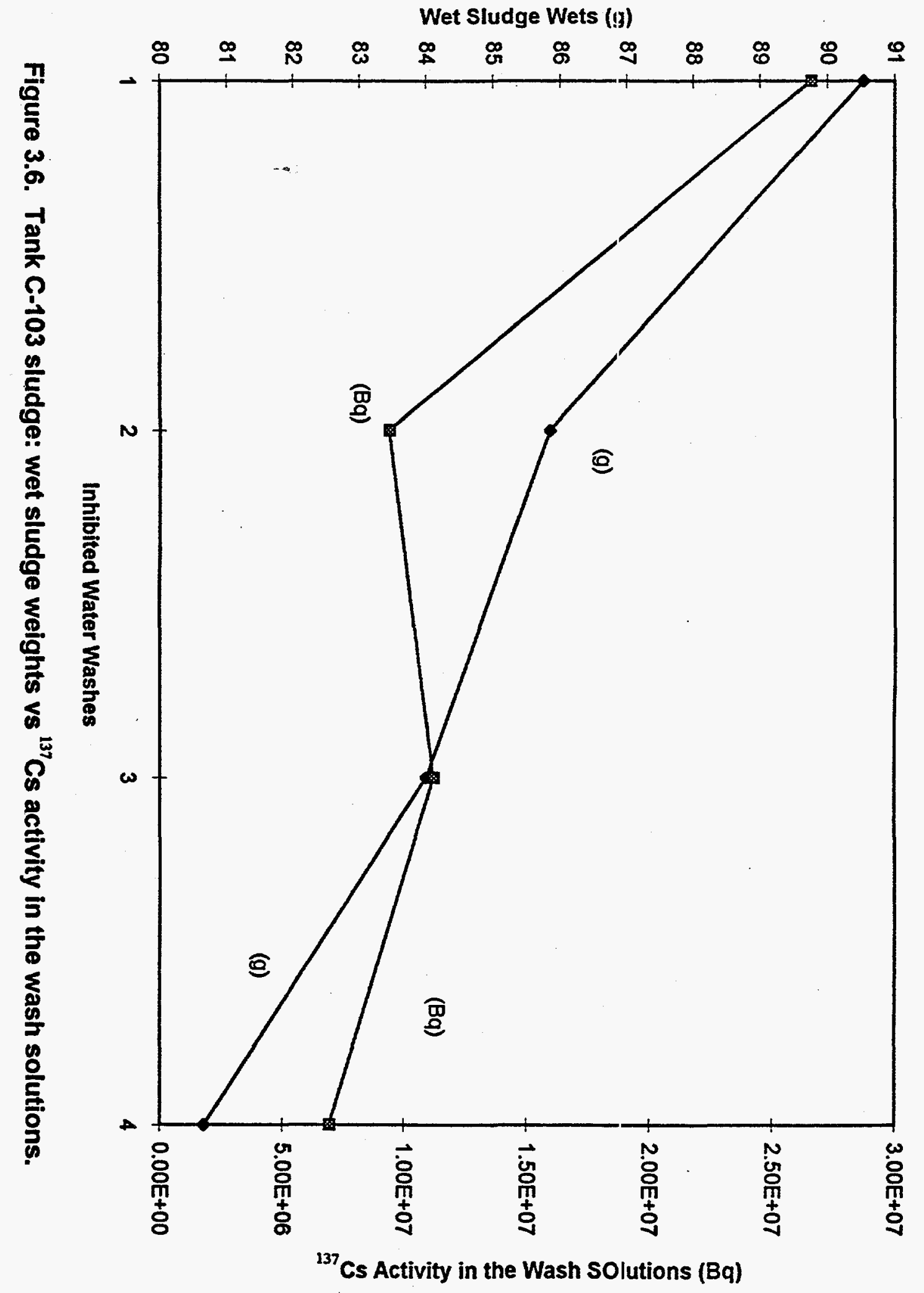


solubilized by a microwave digestion with nitric acid, based on SW-846 Method 3051, Microwave Assisted Acid Digestion of Sediments, Sludges, Soils, and Oils. This method is considered by regulatory agencies to be a total digestion for metals and radionuclides. However, a simple nitric acid treatment will not dissolve most siliceous materials. Therefore, the residue after the microwave-assisted acid digestion was assumed to be silicon dioxide, and the residue was determined gravimetrically.

The leachates and wash solutions were filtered and digested by the SW-846 Method 3015, Microwave Assisted Acid Digestion of Aqueous Samples and Extracts. Each sample was analyzed by the following methods: gross alpha, gross beta, and gamma spectrometry for most of the radionuclides; inductively couple plasma mass spectrometry (ICP-MS) for ${ }^{99} \mathrm{Tc}$; and inductively coupled plasma atomic emission spectroscopy (ICP-AES) for metals. The analytical error for the metal measurements depends upon the analytical method, the concentration level, and the matrix. ICP-AES is a multiple element measurement technique designed for the best average performance for all elements and is not optimized for any single component. When the ${ }^{90} \mathrm{Sr}$ content was measured, the strontium was first precipitated as a carbonate and then mounted for beta counting with a gas-flow proportional counter.

The phosphorus and sulfur levels in the washed and leached sludge samples were determined with an ICP-MS. The phosphate and sulfate concentrations in the wash and leach solutions were measured by ion chromatography with a Dionex Model $4500 \mathrm{i}$ system. The standard radiochemical methods for radioactive waste characterization are EPA Method 600/900.0, Gross Alpha and Beta Radioactivity in Drinking Water, and EPA Method 600/901.1, Gamma Emitting Radionuclides in Drinking Water. EPA Method 901.1 was used to determine ${ }^{60} \mathrm{Co},{ }^{134} \mathrm{Cs},{ }^{137} \mathrm{Cs},{ }^{152} \mathrm{Eu},{ }^{154} \mathrm{Eu},{ }^{155} \mathrm{Eu}$, and ${ }^{241} \mathrm{Am}$. Gross beta measurements were obtained by liquid scintillation counting. In some cases, the plutonium activity was determined by alpha spectrometry after a radiochemical separation.

Since most of the analytical results were reported in milliliters, the density of each wash and leach solution was measured. After the solution was filtered with a $0.45-\mu \mathrm{m}$-porosity syringe filter, the solution was transferred into a preweighed volumetric flask and weighed. 


\section{RESULTS AND DISCUSSION}

\subsection{ANALYSIS: INITIAL WATER WASHES OF SLUDGE FROM TANK S-101}

The initial step in the pretreatment of Hanford tank sludges involves an inhibited water wash of the sludge to remove water-soluble components such as sodium nitrate from the sludge. The effectiveness of the inhibited vater wash on the sludge sample from Hanford Tank S-101 is shown in Table 4.1, which contains the results from the chemical analysis on the untreated sludge, washed solids, and the composite wash solution. Table 4.1 also contains the total mass or radioactivity of key components in the untreated solids, wash solutions, and washed solids. The removal percentages in Table 4.1 were determined by dividing the amount of material in the wash solution by the total amount in the wash solution and the washed solids. This method was chosen because an analysis of a small sample from a much larger sludge sample is not necessarily representative of the larger sample due to sample inhomogeneity.

The primary wash objective is to separate water-soluble and insoluble solids. As expected, the water washes were effective in the removal of potassium $(>99.1 \%)$, ${ }^{99} \mathrm{Tc}(>98.9 \%)$, sodium $(97.9 \%),{ }^{137} \mathrm{Cs}(97.7 \%)$, sulfate $(93.4 \%)$, and phosphate $(79.7 \%)$, while ${ }^{60} \mathrm{Co},{ }^{90} \mathrm{Sr},{ }^{154} \mathrm{Eu},{ }^{155} \mathrm{Eu}$, ${ }^{241} \mathrm{Am},{ }^{244} \mathrm{Cm}$, plutonium, and uranium were not observed in the wash solutions. In addition, the initial water washes were moderatily effective at chromium removal (46.3\%). In FY 1997, PNNL researchers (Lumetta et al., 1997) performed three inhibited water washes on a 1-g sample of sludge from Hanford Tank S-101. The liquid-to-solid ratio in milliliters per gram was over 30 in the PNNL test, while the liquid-to-solid ratio in this study was less than 8 . With the possible exception of potassium, the results: from the two studies were similar. The water washes at PNNL removed at least $31 \%$ of the potassium while essentially all of the potassium was removed by the water washes in this work. As noted earlier, other differences in the water wash results at PNNL and ORNL include the weight percent of soluble solids and weight percent of water in the initial sludge. - At PNNL, the sludge sample from Hanford Tank S-101 contained 42 wt \% watersoluble solids, $22 \mathrm{wt} \%$ water-insoluble solids, and $36 \mathrm{wt} \%$ water, while the sludge in this study contained $30 \mathrm{wt} \%$ water-soluble solids, $21 \mathrm{wt} \%$ water-insoluble solids, and $49 \mathrm{wt} \%$ water. 
Table 4.1. Effects of the inhibited water washes on the sludge from Hanford Tank S-101

\begin{tabular}{|c|c|c|c|c|c|c|c|c|}
\hline & \multicolumn{3}{|c|}{ Untreated Solids } & \multicolumn{2}{|c|}{ Wash Solutions } & \multicolumn{2}{|c|}{ Washed Solids } & \multirow[b]{2}{*}{$\%$ Removed } \\
\hline $\begin{array}{l}\text { Nonradioactive } \\
\text { Component }\end{array}$ & $\left(\mu g / g^{\circ}\right)$ & $\left(\mu \mathrm{g} / \mathrm{g}^{6}\right)$ & $\left(\mu \mathrm{g} / \mathrm{g}^{f}\right)$ & $(\mu \mathrm{g} / \mathrm{mL})$ & $\begin{array}{l}\text { Total } \\
\text { (ug) }\end{array}$ & $(\mu \mathrm{g} / \mathrm{g})$ & $\begin{array}{l}\text { Total } \\
(\mu \mathrm{g})\end{array}$ & \\
\hline $\mathrm{Ag}$ & $<6.1 \mathrm{E} 1$ & $9.04 \mathrm{E} 0$ & 2.15E0 & $2.00 \mathrm{E}-2$ & $1.63 \mathrm{E} 1$ & 2.49EO & $2.22 \mathrm{E} 2$ & 6.8 \\
\hline Al & $1.47 \mathrm{E} 5$ & 8.63E4 & $9.41 \mathrm{E} 4$ & $1.40 \mathrm{E} 3$ & $1.14 \mathrm{E} 6$ & $1.04 \mathrm{E} 5$ & $9.27 \mathrm{E} 6$ & 11.0 \\
\hline $\mathrm{Ba}$ & $6.9 \mathrm{E} 1$ & $4.49 \mathrm{E} 1$ & $3.36 \mathrm{E} 1$ & $1.00 \mathrm{E}-2$ & 8.13E0 & $4.16 \mathrm{E} 1$ & $3.71 \mathrm{E} 3$ & 0.2 \\
\hline $\mathrm{Ca}$ & $1.29 \mathrm{E} 3$ & $1.33 \mathrm{E} 3$ & $5.26 \mathrm{E} 2$ & $3.2 \mathrm{E}-2$ & $2.6 \mathrm{E} 1$ & $6.53 \mathrm{E} 2$ & $5.82 \mathrm{EA}$ & 0.0 \\
\hline $\mathrm{Cr}_{\mathrm{r}}$ & $7.11 \mathrm{E} 3$ & $3.43 \mathrm{E} 3$ & $4.67 \mathrm{E} 3$ & $2.94 \mathrm{E} 2$ & 2.39ES & $3.11 \mathrm{E} 3$ & 2.77E5 & 46.3 \\
\hline $\mathrm{Cu}$ & $9.9 \mathrm{E} 1$ & $5.26 \mathrm{E} 1$ & 5.38E1 & $1.34 \mathrm{E}-1$ & $1.09 \mathrm{E} 2$ & $6.55 \mathrm{E} 2$ & $5.84 \mathrm{E} 3$ & 1.8 \\
\hline $\mathrm{Fe}$ & $2.15 \mathrm{E} 3$ & $1.83 \mathrm{E} 3$ & $1.50 \mathrm{E} 3$ & $1.67 \mathrm{E}-1$ & $1.36 \mathrm{E} 2$ & $1.86 \mathrm{E} 3$ & $1.66 \mathrm{E} 5$ & 0.1 \\
\hline $\mathbf{K}$ & $7.20 \mathrm{E} 2$ & 8.39E2 & $3.54 \mathrm{E} 3$ & $4.78 \mathrm{E} 2$ & $3.88 \mathrm{E} 5$ & $<4.04 \mathrm{E} 1$ & $<3.60 \mathrm{E} 3$ & $>99.1$ \\
\hline $\mathbf{M g}$ & $<.43 \mathrm{E} 2$ & 3.17E1 & $1.07 \mathrm{E} 1$ & $<3.6 \mathrm{E}-2$ & $<.9 \mathrm{E} 1$ & $1.30 \mathrm{E} 1$ & $1.16 \mathrm{E} 3$ & 2.4 \\
\hline $\mathbf{M n}$ & $2.84 \mathrm{E} 3$ & $1.60 \mathrm{E} 3$ & $2.01 \mathrm{E} 3$ & $<1.2 \mathrm{E}-3$ & $<9.8 \mathrm{E}-1$ & $2.49 \mathrm{E} 3$ & $2.22 \mathrm{E} 5$ & 0.0 \\
\hline $\mathrm{Na}$ & $1.80 \mathrm{E} 5$ & $e$ & $1.26 \mathrm{ES}$ & $1.67 \mathrm{E} 4$ & $1.36 \mathrm{E} 7$ & $3.21 \mathrm{E} 3$ & $2.86 \mathrm{ES}$ & 97.9 \\
\hline $\mathbf{N i}$ & $<7.3 \mathrm{E} 1$ & $1.16 \mathrm{E} 2$ & $1.11 \mathrm{E} 2$ & $<8.0 \mathrm{E}-2$ & $<6.5 \mathrm{E} 1$ & $1.37 \mathrm{E} 2$ & $1.22 \mathrm{E} 4$ & $<0.5$ \\
\hline $\mathbf{P}$ & $2.29 \mathrm{E} 3$ & $<8.50 \mathrm{E} 1$ & $3.02 \mathrm{E} 3$ & $2.25 \mathrm{E} 2$ & $1.83 \mathrm{E} 5$ & $1.69 \mathrm{E} 3$ & $1.51 \mathrm{E} 5$ & 54.8 \\
\hline $\mathrm{PO}_{4}$ & $e$ & $e$ & $5.21 \mathrm{E} 3$ & $5.65 \mathrm{E} 2$ & $4.59 \mathrm{E} 5$ & $1.31 \mathrm{E} 3$ & $1.17 \mathrm{ES}$ & 79.7 \\
\hline $\mathrm{Sr}$ & $4.93 \mathrm{E} 2$ & $4.04 \mathrm{E} 2$ & $3.04 \mathrm{E} 2$ & $<1.1 \mathrm{E}-2$ & $<8.94 \mathrm{E} 0$ & 3.77E2 & $3.36 \mathrm{EA}$ & 0.0 \\
\hline $\mathrm{SO}_{4}$ & $e$ & $e$ & 8.81E3 & $1.12 \mathrm{E} 3$ & $9.10 \mathrm{E} 5$ & $7.27 \mathrm{E} 2$ & $6.48 \mathrm{EA}$ & 93.4 \\
\hline Th & $2.43 \mathrm{E} 3$ & $2.40 \mathrm{E} 2$ & $2.59 \mathrm{E} 1$ & $7.88 \mathrm{E}-1$ & $6.40 \mathrm{E} 2$ & $2.49 \mathrm{E} 1$ & $2.22 \mathrm{E} 3$ & 22.4 \\
\hline U & $9.56 \mathrm{E} 3$ & $7.42 \mathrm{E} 3$ & $6.50 \mathrm{E} 3$ & $<1.6 \mathrm{E}-1$ & $<1.30 \mathrm{E}_{2}$ & $8.07 \mathrm{E} 3$ & $7.19 \mathrm{ES}$ & 0.0 \\
\hline v & $<1.21 \mathrm{E} 2$ & $9.73 \mathrm{E} 0$ & $9.45 \mathrm{E} 0$ & $4.88 \mathrm{E}-1$ & $3.97 \mathrm{E} 2$ & $7.27 \mathrm{E} 0$ & $6.48 \mathrm{E} 2$ & 38.0 \\
\hline $\mathrm{Zn}$ & $<1.21 \mathrm{E2}$ & $2.05 \mathrm{E} 2$ & $1.91 \mathrm{E} 2$ & $3.52 \mathrm{E}-1$ & $2.86 \mathrm{E} 2$ & 2.33E2 & $2.08 \mathrm{E} 4$ & 1.4 \\
\hline Radionuclides & $(\mathrm{Bq} / \mathrm{g})$ & $(\mathrm{Bq} / \mathrm{g})$ & $\left(B q / g^{f}\right)$ & $(\mathrm{Bq} / \mathrm{mL})$ & $\begin{array}{l}\text { Total } \\
\text { (Bq) }\end{array}$ & $(\mathrm{B} q / \mathrm{g})$ & $\begin{array}{l}\text { Total } \\
(\mathrm{Bq})\end{array}$ & $\%$ Removed \\
\hline Gross Alpha & $5.03 \mathrm{E} 4$ & $1.50 \mathrm{E} 4$ & $8.16 \mathrm{EA}$ & $<.60 \mathrm{E} 0$ & $<2.11 \mathrm{E} 3$ & $1.01 \mathrm{E} 4$ & $9.00 \mathrm{ES}$ & $<0.2$ \\
\hline Gross Beta & $e$ & $2.90 \mathrm{E} 7$ & $2.56 \mathrm{E} 7$ & $6.30 \mathrm{E} 5$ & $5.12 \mathrm{E} 8$ & $2.60 \mathrm{E} 7$ & 2.32E9 & 18.1 \\
\hline${ }^{2 n 1} \mathrm{Am}$ & $<.59 \mathrm{E} 4$ & e & $4.51 \mathrm{E} 3$ & $8.6 \mathrm{E}-4$ & $<7.0 \mathrm{E}-1$ & $5.60 \mathrm{E} 3$ & $4.99 \mathrm{E} 5$ & 0.0 \\
\hline${ }^{2 \mu} \mathrm{Cm}$ & & $e$ & & $\boldsymbol{g}$ & 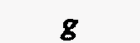 & $2.12 \mathrm{E} 2$ & $1.89 \mathrm{E} 4$ & $0.0^{8}$ \\
\hline${ }^{60} \mathrm{Co}$ & $<1.85 \mathrm{E} 3$ & e & $3.71 \mathrm{E} 2$ & $<1.5 E-4$ & $<1.2 \mathrm{E}-1$ & 4.60E2 & $4.10 \mathrm{E} 4$ & 0.0 \\
\hline${ }^{137} \mathrm{Cs}$ & $5.11 \mathrm{E} 6$ & $3.81 \mathrm{E} 6$ & 4.14E6 & $5.50 \mathrm{E} 5$ & 4.47E8 & $1.20 \mathrm{E} 5$ & $1.07 \mathrm{E} 7$ & 97.7 \\
\hline${ }^{154} \mathrm{Eu}$ & $<.40 \mathrm{E} 3$ & $e$ & $4.03 \mathrm{E} 3$ & $<4.3 E-4$ & $<.5 \mathrm{E}-1$ & $5.00 \mathrm{E} 3$ & $4.46 \mathrm{E} 5$ & 0.0 \\
\hline${ }^{155} \mathrm{Eu}$ & $<1.85 \mathrm{EA}$ & $e$ & $1.77 \mathrm{E} 3$ & $<4.6 \mathrm{E}-4$ & $<.7 \mathrm{E}-1$ & $2.20 \mathrm{E} 3$ & $1.96 \mathrm{E} 5$ & 0.0 \\
\hline $\mathrm{Pu}^{h}$ & $e$ & $9.80 \mathrm{E} 3$ & $7.27 \mathrm{E} 3$ & $2.60 \mathrm{E} 0$ & $2.11 \mathrm{E} 3$ & $9.00 \mathrm{E} 3$ & $8.02 \mathrm{E} 5$ & $<0.3$ \\
\hline $\mathrm{Sr}^{\prime}$ & $1.63 \mathrm{E} 7$ & $\boldsymbol{e}$ & 8.87E6 & $7.00 \mathrm{E} 1$ & $5.69 \mathrm{E} 4$ & $1.10 \mathrm{E} 7$ & $9.81 \mathrm{E} 8$ & 0.0 \\
\hline${ }^{99} \mathrm{Tc}$ & $5.18 \mathrm{E} 3$ & $e$ & $4.62 \mathrm{E} 3$ & $6.23 \mathrm{E} 2$ & $5.06 \mathrm{E} 5$ & $<6.26 \mathrm{E} 1$ & $<5.58 \mathrm{E} 3$ & $>98.9$ \\
\hline
\end{tabular}

"(Lumetta et al., 1997).

b(Egan et al., 1998).

This study is based on the following equation: $[\mu \mathrm{g}$ (wash solution) $+\mu \mathrm{g}$ (washed solids)] $/ 110.61 \mathrm{~g}$.

Percent removals were determined by dividing the amount of material in the wash solution by the total amount in the wash solution and the washed solids.

Not measured.

This study is based on the following equation: $[\mathrm{Bq}$ (wash solution) $+\mathrm{Bq}$ (washed solids) $] / 110.61 \mathrm{~g}$.

${ }^{8}$ Since the gross alpha in the wash solution was below the detection limit, ${ }^{244} \mathrm{Cm}$ was not measured, and the ${ }^{244} \mathrm{Cm}$ concentration is assumed to be $0 \mathrm{~Bq} / \mathrm{mL}$.

${ }^{2} 2.3 \%{ }^{230} \mathrm{Pu}$ and $97.8 \%{ }^{239} \mathrm{Pu}$ and ${ }^{240} \mathrm{Pu}$.

'Based on total radioactive strontium. 
The conductance and ${ }^{137} \mathrm{Cs}$ activity of each of the decanted wash solutions were measured, and the results are presented in Tajle 3.1 and in Figs. 3.3 and 3.4. As expected, the largest changes in conductance and ${ }^{137} \mathrm{Cs}$ activity occurred between the first and second washes, and the conductance and ${ }^{137} \mathrm{Cs}$ activity decreased as the weight of the washed solids decreased. In addition, changes in the conductance and ${ }^{137} \mathrm{Cs}$ activity decreased as the weight changes became smaller. Therefore, conductance and ${ }^{137} \mathrm{Cs}$ activity of the wash solutions can be used to determine when additional water washes will no longer be effective for sludge from Tank S-101.

\subsection{ANALYSIS: SUBSEQUENT LEACHES/WASHES OF SLUDGE FROM TANK S-101}

The primary objective of this ESW study was to determine the effects of sodium hydroxide concentration, temperature, and leaching time on the caustic leaching of sludge from Hanford Tank S-101. The effects of sodium hydroxide concentration and temperature on key components such as aluminum and chromium are given in Table 4.2. The initial water washes removed $11 \%$ of the aluminum, while the combination of water washes and caustic leaches removed $65-92 \%$ of the aluminum. The caustic leaches and subsequent water washes were also effective in the removal of chromium and phosphate. From the initial water washes to the 168-h caustic leaches with water washes, the total chromium removal increased from $46 \%$ to $71-87 \%$ while the total phosphate removal increased from $80 \%$ to $100 \%$. The minimum removal goals for aluminum, chromium, and phosphate were $68 \%, 64 \%$, and $80 \%$, respectively (Colton, 1997). Therefore, the caustic leaches were only required to meet the removal goals for aluminum and chromium. While each combination of sodium hydroxide concentration and temperature could exceed the removal goal for chromium, the $3 \mathrm{M}$ sodium hydroxide leach at $70^{\circ} \mathrm{C}$ failed to meet the aluminum removal goal by $3 \%$. The maximum removal of aluminum and chromium occurred during the leach with $3 \mathrm{M}$ sodium lydroxide at $95^{\circ} \mathrm{C}$, even though this leach condition used the smallest number of moles of sodium hydroxide. It should be noted that the differences in the performance of the $95^{\circ} \mathrm{C}$ leaches viere small.

For the four 168-h samples, the largest reduction in sludge mass occurred with $3 \mathrm{M}$ sodium hydroxide and $95^{\circ} \mathrm{C}$, while the smallest reduction was observed with $1 M$ sodium 
Table 4.2. Leach/wash and ESW results for key components in the sludge from Hanford Tank S-101*

\begin{tabular}{|c|c|c|c|c|}
\hline \multirow[b]{2}{*}{ Component } & \multicolumn{2}{|c|}{$1 M \mathrm{NaOH}$} & \multicolumn{2}{|c|}{$3 M \mathrm{NaOH}$} \\
\hline & $\begin{array}{c}\text { Removal by } \\
\text { leach/wash (\%) }\end{array}$ & $\begin{array}{l}\text { Total removal } \\
\text { by ESW (\%) }\end{array}$ & $\begin{array}{c}\text { Removal by } \\
\text { leach/wash (\%) }\end{array}$ & $\begin{array}{l}\text { Total removal } \\
\text { by ESW (\%) }\end{array}$ \\
\hline \multicolumn{5}{|c|}{ Temperature $=70^{\circ} \mathrm{C}$} \\
\hline Al & 75.7 & 78.4 & 60.6 & 64.9 \\
\hline $\mathrm{Cr}$ & 45.2 & 70.6 & 68.4 & 83.0 \\
\hline $\mathrm{Na}^{b}$ & 39.1 & 98.7 & 26.5 & 98.5 \\
\hline $\mathrm{PO}_{4}$ & $>99.4$ & $>99.9$ & $>99.4$ & $>99.9$ \\
\hline Gross Beta & 0.0 & 18.1 & 0.0 & 18.1 \\
\hline${ }^{137} \mathrm{Cs}$ & 98.6 & 100.0 & 98.3 & 100.0 \\
\hline${ }^{90} \mathrm{Sr}$ & 1.1 & 1.1 & 0.3 & 0.3 \\
\hline${ }^{99} \mathrm{Tc}$ & 72.4 & $>99.7$ & 74.2 & $>99.7$ \\
\hline \multicolumn{5}{|c|}{ Temperature $=95^{\circ} \mathrm{C}$} \\
\hline $\mathrm{Al}$ & 87.6 & 89.0 & 90.4 & 91.5 \\
\hline $\mathrm{Cr}$ & 65.9 & 81.7 & 74.8 & 86.5 \\
\hline $\mathrm{Na}^{\mathrm{b}}$ & 20.9 & 98.3 & $d$ & $>96.0$ \\
\hline $\mathrm{PO}_{4}$ & $>99.7$ & $>99.9$ & $>99.6$ & $>99.9$ \\
\hline Gross Beta & 0.0 & 18.1 & 0.0 & 18.1 \\
\hline${ }^{137} \mathrm{Cs}$ & 80.0 & 99.5 & 79.7 & 99.5 \\
\hline${ }^{90} \mathrm{Sr}^{\mathrm{c}}$ & 0.5 & 0.5 & $e$ & $e$ \\
\hline${ }^{99} \mathrm{Tc}$ & 81.6 & $>99.8$ & 79.5 & $>99.8$ \\
\hline
\end{tabular}

The percent removal by the leach/wash was obtained by dividing the amount of the component in the leached residue by the amount of component in the washed sludge. The percentage of total removal by the ESW is based on the fractions of the component that were removed during the initial water washes $(x)$ and the leach/wash $(y)$. The following equation was used to obtain the percentage of total removal: $\left[x+(1-x)^{*} y\right]^{*} 100$.

${ }^{b}$ It is impossible to determine the amount of sodium removed from the sludge due to the amount of sodium added as sodium hydroxide during the leaching procedure. The reported values were determined by comparing the amounts of sodium in the solids before and after the treatment.

'Based on total strontium in the leach solutions.

Not meaningful.

Not measured. 
hydroxide and $70^{\circ} \mathrm{C}$. The difference in the weight reduction between these two extremes in leach conditions was over a factor of two. In addition, the gravimetric results indicated that temperature is a more critical factor in sludge mass reduction than sodium hydroxide concentration.

The effects of leaching time are shown in Table 4.3 and in Figs. 4.1-4.3. The concentrations of aluminum and chromium in the leach solutions always increased as the leaching time was increased. The significant increase in the aluminum and chromium concentrations between the 72- and 168-h leaches indicates that the leach process may have not reached equilibrium conditions after $168 \mathrm{~h}$. In contrast, most of the phosphate concentrations decreased from the 72 -h leaches to the 168 - $\mathrm{h}$ leaches, while the ${ }^{137} \mathrm{Cs}$ activity was essentially the same for all leachates. Other components that were detected in the leachates included barium, copper, iron, magnesium, sulfate, thorium, vanadium, and zinc.

Another key element in the processing of the leachates is silicon because it can react with sodium to form sodium silicate gels after the filtered leachates are permitted to cool. Attempts to measure silicon content in the washed and the leached/washed solids were not successful. It is assumed that all of the solids after the microwave-assisted acid digestion are silicon dioxide. However, the amount of acid-insoluble solids increased during the ESW process. For the $70^{\circ} \mathrm{C}$ leach with 1 and $3 \mathrm{M}$ sodium hydroxide, the amount of acid-insoluble solids increased from $9.96 \mathrm{E} 3 \mu \mathrm{g}$ to $1.52 \mathrm{E} 5 \mu \mathrm{g}$ and from $1.37 \mathrm{E} 4 \mu \mathrm{g}$ to $1.01 \mathrm{E} 5 \mu \mathrm{g}$, respectively. For the $95^{\circ} \mathrm{C}$ leach with $1 M$ and $3 \mathrm{M}$ sodium hydroxide, the amount of acid-insoluble solids increased from $1.02 \mathrm{E} 4 \mu \mathrm{g}$ to $1.29 \mathrm{E} 5 \mu \mathrm{g}$ and from $9.99 \mathrm{E} 3 \mu \mathrm{g}$ to $5.30 \mathrm{E} 4 \mu \mathrm{g}$, respectively. Therefore, the silicon dioxide assumption is not valid with these samples because the ESW process cannot lead to increase in the amount of silicon dioxide. However, the ESW process with sludge from Tank S-101 does generate an significant increase in the amount of acid-insoluble solids.

Additional evidence that the chemistry of the ESW process is complex can be found in Table 3.2. With three or four of the leach tests, the dry weight of the leached/washed solids was greater than the dry weight of the initial washed solids, and these tests were the 5- and 24-h leaches with 1 and $3 \mathrm{M}$ sodium hydroxide at $70^{\circ} \mathrm{C}$. However, the results from the 24 -h leach with $1 \mathrm{M}$ sodium hydroxide at $70^{\circ} \mathrm{C}$ were not conclusive due to a probable error during the drying 
Table 4.3 Concentrations of key components in the leachates and in the leached solids from the Tank S-101 sludge sample

( $1 \mathrm{MNaOH}$ and $70^{\circ} \mathrm{C}$ )

\begin{tabular}{|c|c|c|c|c|c|c|c|c|c|c|c|}
\hline \multirow[t]{2}{*}{ Component } & \multicolumn{2}{|c|}{$\begin{array}{l}\text { Washed solids } \\
\text { (168 h) }\end{array}$} & \multirow{2}{*}{$\begin{array}{c}\begin{array}{c}5 \mathrm{~h} \\
\text { leach }\end{array} \\
\mu \mathrm{g} / \mathrm{mL}\end{array}$} & \multirow{2}{*}{$\begin{array}{c}24 \mathrm{~h} \\
\text { leach }\end{array}$} & \multirow{2}{*}{$\begin{array}{r}\begin{array}{r}72 \mathrm{~h} \\
\text { leach }\end{array} \\
\mu \mathrm{g} / \mathrm{mL}\end{array}$} & \multicolumn{2}{|c|}{$\begin{array}{l}168 \mathrm{~h} \\
\text { leach }\end{array}$} & \multicolumn{2}{|c|}{$\begin{array}{l}\text { Final washes } \\
(168 \mathrm{~h})\end{array}$} & \multicolumn{2}{|c|}{$\begin{array}{l}\text { Leached solids } \\
\qquad(168 \mathrm{~h})\end{array}$} \\
\hline & $\mu \mathrm{g} / \mathrm{g}$ & $\begin{array}{c}\text { Total } \\
\mu \mathrm{g}\end{array}$ & & & & $\mu \mathrm{g} / \mathrm{mL}$ & $\begin{array}{c}\text { Total } \\
\mu \mathrm{g}\end{array}$ & $\mu \mathrm{g} / \mathrm{mL}$ & $\begin{array}{c}\text { Total } \\
\mu \mathrm{g}\end{array}$ & $\mu \mathrm{g} / \mathrm{g}$ & $\begin{array}{c}\text { Total } \\
\mu_{\mathbf{g}}\end{array}$ \\
\hline $\mathrm{Ag}$ & $2.49 \mathrm{E} 0$ & $1.24 \mathrm{E} 1$ & $a$ & $a$ & $a$ & $a$ & $a$ & $a$ & $a$ & 3.05E0 & $1.16 \mathrm{E} 1$ \\
\hline Al & $1.04 \mathrm{E} 5$ & $5.18 \mathrm{ES}$ & $8.63 \mathrm{El}$ & $5.01 \mathrm{E} 2$ & $8.60 \mathrm{E} 2$ & $1.26 \mathrm{E} 3$ & $2.39 \mathrm{E} 5$ & $4.49 \mathrm{E} 1$ & $3.52 \mathrm{E} 3$ & $3.32 \mathrm{EA}$ & $1.26 \mathrm{E} 5$ \\
\hline $\mathrm{Ba}$ & $4.16 \mathrm{El}$ & $2.07 \mathrm{E} 2$ & $a$ & $4.50 \mathrm{E}-2$ & $4.50 \mathrm{E}-2$ & $4.50 \mathrm{E}-2$ & 8.53E0 & $4.50 \mathrm{E}-2$ & $3.53 \mathrm{E} 0$ & $5.70 \mathrm{E} 1$ & 2.17E2 \\
\hline $\mathrm{Ca}$ & $6.53 \mathrm{E} 2$ & $3.25 \mathrm{E} 3$ & $a$ & $a$ & $a$ & $a$ & $a$ & $a$ & $a$ & $5.98 \mathrm{E} 2$ & $2.28 \mathrm{E} 3$ \\
\hline $\mathrm{Cr}$ & $3.11 \mathrm{E} 3$ & $1.55 \mathrm{E} 4$ & $7.59 \mathrm{EO}$ & $2.80 \mathrm{El}$ & $3.96 \mathrm{E} 1$ & $4.77 \mathrm{E} 1$ & $9.04 \mathrm{E} 3$ & $1.93 \mathrm{EO}$ & $1.51 \mathrm{E} 2$ & $2.23 \mathrm{E} 3$ & $8.49 \mathrm{E} 3$ \\
\hline $\mathrm{Cu}$ & $6.55 \mathrm{E} 1$ & $3.26 \mathrm{E} 2$ & $2.62 \mathrm{E}-1$ & $6.55 \mathrm{E}-1$ & $5.75 \mathrm{E}-1$ & $5.25 \mathrm{E}-1$ & $9.95 \mathrm{E} 1$ & $5.00 \mathrm{E}-2$ & $3.92 \mathrm{EO}$ & $7.00 \mathrm{E} 1$ & $2.67 \mathrm{E} 2$ \\
\hline $\mathrm{Fe}$ & $1.86 \mathrm{E} 3$ & $9.26 \mathrm{E} 3$ & $2.09 \mathrm{E}-1$ & $6.85 \mathrm{E}-1$ & $1.31 \mathrm{E} 0$ & $1.40 \mathrm{E} 0$ & $2.65 \mathrm{E} 2$ & $3.50 \mathrm{E}-2$ & 2.75E 0 & $2.06 \mathrm{E} 3$ & $7.85 \mathrm{E} 3$ \\
\hline $\mathbf{M g}$ & $1.30 \mathrm{E} 1$ & $6.47 \mathrm{E} 1$ & $a$ & $a$ & $a$ & $a$ & $a$ & $a$ & $a$ & $2.24 \mathrm{El}$ & $8.53 \mathrm{E} 1$ \\
\hline Mn & $2.49 \mathrm{E} 3$ & $1.24 \mathrm{E} 4$ & $a$ & $a$ & $a$ & $a$ & $a$ & $a$ & $a$ & $3.01 \mathrm{E} 3$ & $1.15 \mathrm{E} 4$ \\
\hline $\mathrm{Na}$ & $3.21 \mathrm{E} 3$ & $1.60 \mathrm{EA}$ & $2.21 \mathrm{EA}$ & $2.31 E 4$ & $2.28 \mathrm{E} 4$ & $2.09 \mathrm{E} 4$ & $3.96 \mathrm{E} 6$ & $1.04 \mathrm{E} 3$ & $8.16 \mathrm{EA}$ & $2.56 \mathrm{E} 3$ & $9.75 \mathrm{E} 3$ \\
\hline $\mathrm{Ni}$ & $1.37 \mathrm{E} 2$ & $6.82 \mathrm{E} 2$ & $a$ & $a$ & $a$ & $a$ & $a$ & $a$ & $a$ & $1.95 \mathrm{E} 2$ & $7.43 \mathrm{E} 2$ \\
\hline $\mathrm{PO}_{4}$ & $1.31 \mathrm{E} 3$ & $6.52 \mathrm{E} 3$ & $a$ & $1.82 \mathrm{E} 1$ & $2.41 \mathrm{E} 1$ & $2.10 \mathrm{E} 1$ & $3.98 \mathrm{E} 3$ & $1.95 \mathrm{E} 1$ & $1.53 \mathrm{E} 3$ & $\dot{a}$ & $a$ \\
\hline $\mathrm{SO}_{4}$ & $7.27 \mathrm{E} 2$ & $3.62 \mathrm{E} 3$ & 2.54E0 & $a$ & $1.18 \mathrm{E} 1$ & $a$ & $a$ & $a$ & $a$ & $a$ & $a$ \\
\hline Th & $2.49 \mathrm{E} 1$ & $1.24 \mathrm{E} 2$ & $5.68 \mathrm{E}-1$ & $1.19 \mathrm{EO}$ & $1.25 \mathrm{E} 0$ & $1.24 \mathrm{E} 0$ & $2.35 \mathrm{E} 2$ & $a$ & $a$ & $a$ & $a$ \\
\hline $\mathrm{U}$ & 8.07E3 & $4.02 \mathrm{EA}$ & $a$ & $a$ & $a$ & $a$ & $a$ & $a$ & $a$ & $9.51 \mathrm{E} 3$ & $3.62 \mathrm{EA}$ \\
\hline $\mathrm{v}$ & $7.27 \mathrm{E} 0$ & $3.62 \mathrm{E} 1$ & $a$ & $1.20 \mathrm{E}-1$ & $1.35 \mathrm{E}-1$ & $1.55 \mathrm{E}-1$ & $2.94 \mathrm{E} 1$ & $9.00 \mathrm{E}-2$ & $7.06 \mathrm{E} 0$ & $a$ & $a$ \\
\hline $\mathrm{Zn}$ & 2.33E2 & $1.16 \mathrm{E} 3$ & $5.91 \mathrm{E}-1$ & $a$ & $a$ & $a$ & $a$ & $a$ & $a$ & $6.87 \mathrm{E} 1$ & $2.62 \mathrm{E} 2$ \\
\hline
\end{tabular}


Table 4.3 (continued)

(1 $\mathrm{M} \mathrm{NaOH}$ and $95^{\circ} \mathrm{C}$ )

\begin{tabular}{|c|c|c|c|c|c|c|c|c|c|c|c|}
\hline \multirow[t]{2}{*}{ Component } & \multicolumn{2}{|c|}{$\begin{array}{l}\text { Washed solids } \\
(168 \mathrm{~h})\end{array}$} & \multirow{2}{*}{$\frac{\begin{array}{c}5 \mathrm{~h} \\
\text { leach }\end{array}}{\mu \mathrm{g} / \mathrm{mL}}$} & \multirow{2}{*}{$\begin{array}{c}24 \mathrm{~h} \\
\text { leach }\end{array}$} & \multirow{2}{*}{$\begin{array}{c}\begin{array}{c}72 \mathrm{~h} \\
\text { leach }\end{array} \\
\mu \mathrm{g} / \mathrm{mL}\end{array}$} & \multicolumn{2}{|c|}{$\begin{array}{l}168 \mathrm{~h} \\
\text { leach }\end{array}$} & \multicolumn{2}{|c|}{$\begin{array}{c}\text { Final washes } \\
(168 \mathrm{~h})\end{array}$} & \multicolumn{2}{|c|}{$\begin{array}{c}\text { Leached solids } \\
(168 \mathrm{~h})\end{array}$} \\
\hline & $\mu \mathrm{g} / \mathrm{g}$ & $\begin{array}{c}\text { Total } \\
\mu \mathrm{g}\end{array}$ & & & & $\mu \mathrm{g} / \mathrm{mL}$ & $\begin{array}{c}\text { Total } \\
\mu \mathrm{g}\end{array}$ & $\mu \mathrm{g} / \mathrm{mL}$ & $\begin{array}{c}\text { Total } \\
\mu \mathrm{g} \\
\end{array}$ & $\mu \mathrm{g} / \mathrm{g}$ & $\begin{array}{c}\text { Total } \\
\mu \mathrm{g}\end{array}$ \\
\hline $\mathrm{Ag}_{\mathbf{g}}$ & $2.49 \mathrm{E} 0$ & $1.27 \mathrm{El}$ & $a$ & $a$ & $a$ & $a$ & $a$ & $a$ & $a$ & $6.06 \mathrm{E} 0$ & $1.40 \mathrm{E} 1$ \\
\hline Al & $1.04 \mathrm{E} 5$ & $5.29 \mathrm{E} 5$ & $1.62 \mathrm{E} 3$ & $2.64 \mathrm{E} 3$ & $3.61 \mathrm{E} 3$ & $4.95 \mathrm{E} 3$ & 4.27E5 & $7.53 \mathrm{E} 1$ & $5.74 \mathrm{E} 3$ & $2.84 \mathrm{EA}$ & $6.54 \mathrm{E} 4$ \\
\hline $\mathrm{Ba}$ & $4.16 \mathrm{El}$ & $2.11 \mathrm{E2}$ & $a$ & $a$ & $\overline{2} . \bar{y} \mathbf{U} \bar{E}-\mathbf{i}$ & 4. $\hat{\partial U} \overline{\mathrm{E}}-\hat{z}$ & 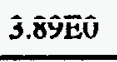 & $\mathbf{a}$ & a & i. $.00 \bar{E} 2$ & $2.49 \mathrm{E} 2$ \\
\hline $\mathrm{Ca}$ & $6.53 \mathrm{E} 2$ & $3.32 \mathrm{E} 3$ & $a$ & $a$ & $a$ & $a$ & $a$ & $a$ & $a$ & $a$ & $a$ \\
\hline $\mathrm{Cr}$ & $3.11 \mathrm{E} 3$ & $1.58 \mathrm{E} 4$ & $4.21 \mathrm{El}$ & $8.96 \mathrm{El}$ & $1.18 \mathrm{E} 2$ & $1.49 \mathrm{E} 2$ & $1.29 \mathrm{E} 4$ & $2.89 \mathrm{E} 0$ & $2.20 \mathrm{E} 2$ & $2.34 \mathrm{E} 3$ & $5.39 \mathrm{E} 3$ \\
\hline $\mathrm{Cu}$ & $6.55 \mathrm{E} 1$ & 3.33E2 & $5.19 \mathrm{E}-1$ & $5.66 \mathrm{E}-1$ & $6.25 \mathrm{E}-1$ & $7.35 \mathrm{E}-1$ & $6.35 \mathrm{E} 1$ & $a$ & $a$ & $1.46 \mathrm{E} 2$ & $3.36 \mathrm{E} 2$ \\
\hline $\mathrm{Fe}$ & $1.86 \mathrm{E} 3$ & $9.45 \mathrm{E} 3$ & $1.37 \mathrm{E} 0$ & $2.62 \mathrm{E} 0$ & $1.41 \mathrm{E} 0$ & $1.69 \mathrm{E} 0$ & $1.46 \mathrm{E} 2$ & $a$ & $a$ & $4.27 \mathrm{E} 3$ & $9.83 \mathrm{E} 3$ \\
\hline Mg & $1.30 \mathrm{El}$ & $6.61 \mathrm{E} 1$ & $a$ & $a$ & $a$ & $a$ & a. & $a$ & $a$ & $5.61 \mathrm{E} 1$ & $1.29 \mathrm{E} 2$ \\
\hline $\mathrm{Mn}$ & $2.49 \mathrm{E} 3$ & $1.27 \mathrm{E} 4$ & $a$ & $a$ & $a$ & $a$ & $a$ & $a$ & $a$ & $a$ & $a$ \\
\hline $\mathrm{Na}$ & $3.21 \mathrm{E} 3$ & $1.63 \mathrm{E} 4$ & $2.01 \mathrm{E} 4$ & $2.05 \mathrm{E} 4$ & 2.17EA & $2.40 \mathrm{E} A$ & $2.07 \mathrm{E} 6$ & 7.92E2 & $6.04 \mathrm{EA}$ & $5.61 \mathrm{E} 3$ & $1.29 \mathrm{E} 4$ \\
\hline $\mathrm{Ni}$ & $1.37 \mathrm{E} 2$ & $6.96 \mathrm{E} 2$ & $a$ & $a$ & $a$ & $a$ & $a$ & $a$ & $a$ & $3.54 \mathrm{E} 2$ & 8.15E2 \\
\hline $\mathrm{PO}_{4}$ & $1.31 \mathrm{E} 3$ & $6.66 \mathrm{E} 3$ & $a$ & $a$ & $1.49 \mathrm{E} 1$ & $1.74 \mathrm{E} 1$ & $1.50 \mathrm{E3}$ & $a$ & $a$ & $a$ & $a$ \\
\hline $\mathrm{SO}_{4}$ & $7.27 \mathrm{E} 2$ & $3.69 \mathrm{E} 3$ & $1.51 \mathrm{E} 0$ & $1.54 \mathrm{E} 0$ & $1.17 \mathrm{E} 1$ & $a$ & $a$ & $a$ & $a$ & $a$ & $a$ \\
\hline Th & $2.49 \mathrm{E} 1$ & $1.27 \mathrm{E} 2$ & $5.63 \mathrm{E}-1$ & $6.62 \mathrm{E}-1$ & $1.58 \mathrm{E} 0$ & $1.65 \mathrm{E} 0$ & $1.42 \mathrm{E} 2$ & $a$ & $a$ & $a$ & $a$ \\
\hline $\mathrm{U}$ & $8.07 \mathrm{E} 3$ & $4.10 \mathrm{E} A$ & $a$ & $a$ & $a$ & $a$ & $a$ & $a$ & $a$ & $1.61 \mathrm{EA}$ & $3.71 \mathrm{EA}$ \\
\hline $\mathrm{v}$ & $7.27 \mathrm{E} 0$ & $3.69 \mathrm{E} 1$ & $a$ & $a$ & $1.85 \mathrm{E}-1$ & $2.05 \mathrm{E}-1$ & $1.77 \mathrm{E} 1$ & $a$ & $a$ & $a$ & $a$ \\
\hline $\mathrm{Zn}$ & 2.33E2 & $1.18 \mathrm{E} 3$ & $a$ & $a$ & $1.37 \mathrm{E} 0$ & $a$ & $a$ & $a$ & $a$ & $1.26 \mathrm{E} 2$ & $2.90 \mathrm{E} 2$ \\
\hline
\end{tabular}


Table 4.3 (continued)

(3 $\mathrm{M} \mathrm{NaOH}$ and $70^{\circ} \mathrm{C}$ )

\begin{tabular}{|c|c|c|c|c|c|c|c|c|c|c|c|}
\hline \multirow[t]{2}{*}{ Component } & \multicolumn{2}{|c|}{$\begin{array}{l}\text { Washed solids } \\
(168 \mathrm{~h})\end{array}$} & \multirow{2}{*}{$\begin{array}{c}\begin{array}{c}5 \mathrm{~h} \\
\text { leach }\end{array} \\
\mu \mathrm{g} / \mathrm{mL}\end{array}$} & \multirow{2}{*}{$\begin{array}{r}24 \mathrm{~h} \\
\text { leach }\end{array}$} & \multirow{2}{*}{$\begin{array}{c}\begin{array}{c}72 \mathrm{~h} \\
\text { leach }\end{array} \\
\mu \mathrm{g} / \mathrm{mL}\end{array}$} & \multicolumn{2}{|c|}{$\begin{array}{l}168 \mathrm{~h} \\
\text { leach }\end{array}$} & \multicolumn{2}{|c|}{$\begin{array}{l}\text { Final washes } \\
(168 \mathrm{~h})\end{array}$} & \multicolumn{2}{|c|}{$\begin{array}{l}\text { Leached solids } \\
\qquad(168 \mathrm{~h})\end{array}$} \\
\hline & $\mu \mathrm{g} / \mathrm{g}$ & $\begin{array}{c}\text { Total } \\
\mu \mathrm{g}\end{array}$ & & & & $\mu \mathrm{g} / \mathrm{mL}$ & $\begin{array}{c}\text { Total } \\
\mu \mathrm{g}\end{array}$ & $\mu \mathrm{g} / \mathrm{mL}$ & $\begin{array}{c}\text { Total } \\
\mu \mathrm{g}\end{array}$ & $\mu \mathrm{g} / \mathrm{g}$ & $\begin{array}{c}\text { Total } \\
\mu \mathrm{g}\end{array}$ \\
\hline $\mathrm{Ag}$ & $2.49 \mathrm{E} 0$ & $1.70 \mathrm{E} 1$ & $a$ & $a$ & $a$ & $a$ & $a$ & $a$ & $a$ & $3.12 \mathrm{E} 0$ & $1.75 \mathrm{EI}$ \\
\hline Al & $1.04 \mathrm{ES}$ & $7.10 \mathrm{E} 5$ & $3.34 \mathrm{E} 2$ & $1.17 \mathrm{E} 3$ & $3.10 \mathrm{E} 3$ & $5.68 \mathrm{E} 3$ & $3.62 \mathrm{E} 5$ & $4.69 \mathrm{E} 2$ & $3.76 \mathrm{EA}$ & $4.98 \mathrm{E} 4$ & $2.80 \mathrm{E} 5$ \\
\hline $\mathrm{Ba}$ & $4.16 \mathrm{E} 1$ & $2.84 \mathrm{E} 2$ & $a$ & $4.50 \mathrm{E}-2$ & $4.50 \mathrm{E}-2$ & $a$ & $a$ & $a$ & $a$ & $5.36 \mathrm{E} 1$ & $3.01 \mathrm{E} 2$ \\
\hline $\mathrm{Ca}$ & $6.53 \mathrm{E} 2$ & $4.46 \mathrm{E} 3$ & $a$ & $a$ & $a$ & $a$ & $a$ & $a$ & $a$ & $5.88 \mathrm{E} 2$ & $3.31 \mathrm{E} 3$ \\
\hline $\mathrm{Cr}$ & $3.11 \mathrm{E} 3$ & $2.12 \mathrm{EA}$ & $4.83 \mathrm{E} 1$ & $1.33 \mathrm{E} 2$ & $2.01 \mathrm{E} 2$ & $2.92 \mathrm{E} 2$ & $1.86 \mathrm{E} 4$ & $2.30 \mathrm{E} 1$ & $1.85 \mathrm{E} 3$ & $1.19 \mathrm{E} 3$ & $6.69 \mathrm{E} 3$ \\
\hline $\mathrm{Cu}$ & $6.55 \mathrm{E} 1$ & $4.47 \mathrm{E} 2$ & $2.06 \mathrm{EO}$ & $6.13 \mathrm{E} 0$ & $4.76 \mathrm{EO}$ & $7.95 \mathrm{EO}$ & $5.07 \mathrm{E} 2$ & $1.59 \mathrm{E}-1$ & $1.28 \mathrm{El}$ & $5.91 \mathrm{El}$ & $3.32 \mathrm{E} 2$ \\
\hline $\mathrm{Fe}$ & $1.86 \mathrm{E} 3$ & $1.27 \mathrm{E} 4$ & $7.04 \mathrm{E}-1$ & $3.02 \mathrm{EO}$ & $7.04 \mathrm{E} 0$ & $9.12 \mathrm{E}-1$ & $5.81 \mathrm{E} 1$ & $1.69 \mathrm{E}-1$ & $1.36 \mathrm{E} 1$ & $2.19 \mathrm{E} 3$ & $1.23 \mathrm{E} 4$ \\
\hline $\mathbf{M g}$ & $1.30 \mathrm{E} 1$ & 8.88E1 & $a$ & $a$ & $a$ & $a$ & $a$ & $a$ & $a$ & $2.95 \mathrm{E} 1$ & $1.66 \mathrm{E} 2$ \\
\hline $\mathbf{M n}$ & $2.49 \mathrm{E} 3$ & $1.70 \mathrm{E} 4$ & $a$ & $2.00 \mathrm{E}-2$ & $a$ & $a$ & $a$ & $a$ & $a$ & $2.71 \mathrm{E} 3$ & $1.52 \mathrm{E} 4$ \\
\hline $\mathrm{Na}$ & $3.21 \mathrm{E3}$ & $2.19 \mathrm{E} 4$ & $6.13 \mathrm{E} 4$ & $7.11 \mathrm{EA}$ & $7.25 \mathrm{E} 4$ & $6.80 \mathrm{EA}$ & 4.34E6 & $6.00 \mathrm{E} 3$ & $4.81 \mathrm{E} 5$ & $2.86 \mathrm{E} 3$ & $1.61 \mathrm{EA}$ \\
\hline $\mathrm{Ni}$ & $1.37 \mathrm{E} 2$ & $9.35 \mathrm{E} 2$ & $a$ & $a$ & $a$ & $a$ & $a$ & $a$ & $a$ & $1.22 \mathrm{E} 3$ & $6.86 \mathrm{E} 3$ \\
\hline $\mathrm{PO}_{4}$ & $1.31 \mathrm{E} 3$ & $8.94 \mathrm{E} 3$ & $a$ & $2.03 \mathrm{E} 1$ & $2.76 \mathrm{E} 1$ & $1.99 \mathrm{E} 1$ & $1.27 \mathrm{E} 3$ & $a$ & $a$ & $a$ & $a$ \\
\hline $\mathrm{SO}_{4}$ & $7.27 \mathrm{E} 2$ & $4.96 \mathrm{E} 3$ & $a$ & $a$ & $a$ & $a$ & $a$ & $a$ & $a$ & $a$ & $a$ \\
\hline Th & $2.49 \mathrm{E} 1$ & $1.70 \mathrm{E} 2$ & $4.81 \mathrm{E}-1$ & $1.93 \mathrm{EO}$ & $1.95 \mathrm{E} 0$ & $5.28 \mathrm{E}-1$ & $3.37 \mathrm{El}$ & $a$ & $a$ & $2.52 \mathrm{E} 1$ & $1.42 \mathrm{E} 2$ \\
\hline $\mathrm{U}$ & 8.07E3 & $5.51 \mathrm{E} 4$ & $a$ & $a$ & $a$ & $a$ & $a$ & $a$ & $a$ & $8.28 \mathrm{E} 3$ & $4.65 \mathrm{E} A$ \\
\hline $\mathrm{v}$ & $7.27 \mathrm{E} 0$ & $4.96 \mathrm{E} 1$ & $a$ & $1.55 \mathrm{E}-1$ & $1.75 \mathrm{E}-1$ & $a$ & $a$ & $a$ & $a$ & $a$ & $a$ \\
\hline $2 n$ & 2.33E2 & $1.59 \mathrm{E} 3$ & $a$ & $1.02 \mathrm{EO}$ & 8.95E-1 & $3.18 \mathrm{E} 0$ & 2.03E 2 & $a$ & $a$ & $1.45 \mathrm{E} 2$ & $8.15 \mathrm{E} 2$ \\
\hline
\end{tabular}


Table 4.3 (continued)

(3 $\mathrm{M} \mathrm{NaOH}$ and $95^{\circ} \mathrm{C}$ )

\begin{tabular}{|c|c|c|c|c|c|c|c|c|c|c|c|}
\hline \multirow[t]{2}{*}{ Component } & \multicolumn{2}{|c|}{$\begin{array}{c}\text { Washed solids } \\
(168 \mathrm{~h})\end{array}$} & \multirow{2}{*}{$\begin{array}{c}5 \mathrm{~h} \\
\text { leach }\end{array}$} & \multirow{2}{*}{$\frac{\begin{array}{c}24 \mathrm{~h} \\
\text { leach }\end{array}}{\mu \mathrm{g} / \mathrm{mL}}$} & \multirow{2}{*}{$\frac{\begin{array}{r}72 \mathrm{~h} \\
\text { leach }\end{array}}{\mu \mathrm{g} / \mathrm{mL}}$} & \multicolumn{2}{|c|}{$\begin{array}{l}168 \mathrm{~h} \\
\text { leach }\end{array}$} & \multicolumn{2}{|c|}{$\begin{array}{c}\text { Final washes } \\
(168 \mathrm{~h})\end{array}$} & \multicolumn{2}{|c|}{$\begin{array}{l}\text { Leached solids } \\
\text { (168 h) }\end{array}$} \\
\hline & $\mu \mathrm{g} / \mathrm{g}$ & $\begin{array}{c}\text { Total } \\
\mu \mathrm{g}\end{array}$ & & & & $\mu \mathrm{g} / \mathrm{mL}$ & $\begin{array}{c}\text { Total } \\
\mu \mathrm{g}\end{array}$ & $\mu \mathrm{g} / \mathrm{mL}$ & $\begin{array}{c}\text { Total } \\
\mu \mathrm{g}\end{array}$ & $\mu \mathbf{g} / \mathbf{g}$ & $\begin{array}{c}\text { Total } \\
\mu \mathrm{g}\end{array}$ \\
\hline $\mathrm{Ag}$ & $2.49 \mathrm{E} 0$ & $1.24 \mathrm{E} 1$ & $a$ & $a$ & $a$ & $a$ & $a$ & $a$ & $a$ & 8.17E0 & 1.17E1 \\
\hline $\mathrm{Al}$ & $1.04 \mathrm{E} 5$ & $5.20 \mathrm{ES}$ & $4.67 \mathrm{E} 3$ & $9.95 \mathrm{E} 3$ & $1.09 \mathrm{EA}$ & $1.34 \mathrm{EA}$ & $4.05 \mathrm{E} 5$ & $1.04 \mathrm{E} 2$ & $8.09 \mathrm{E} 3$ & $3.48 \mathrm{E} 4$ & $4.98 \mathrm{E} 4$ \\
\hline $\mathrm{Ba}$ & $4.16 \mathrm{E} 1$ & $2.08 \mathrm{E} 2$ & $a$ & $a$ & $a$ & $a$ & $a$ & $a$ & $a$ & $1.49 \mathrm{E} 2$ & $2.13 \mathrm{E} 2$ \\
\hline $\mathrm{Ca}$ & $6.53 \mathrm{E} 2$ & $3.26 \mathrm{E} 3$ & $a$ & $a$ & $a$ & $a$ & $a$ & $a$ & $a$ & $1.38 \mathrm{E} 3$ & $1.98 \mathrm{E} 3$ \\
\hline $\mathrm{Cr}$ & $3.11 \mathrm{E} 3$ & $1.55 \mathrm{E} 4$ & $7.12 \mathrm{E} 1$ & 2.35E2 & $3.74 \mathrm{E} 2$ & 4.07E2 & $1.23 \mathrm{E} 4$ & $3.28 \mathrm{E} 0$ & $2.55 \mathrm{E} 2$ & $2.73 \mathrm{E} 3$ & $3.91 \mathrm{E} 3$ \\
\hline $\mathrm{Cu}$ & $6.55 \mathrm{E} 1$ & $3.27 \mathrm{E} 2$ & $5.23 \mathrm{EO}$ & $4.48 \mathrm{E} 0$ & 3.70EO & $4.18 \mathrm{E} 0$ & $1.26 \mathrm{E} 2$ & $a$ & $a$ & $1.13 \mathrm{E} 2$ & $1.62 \mathrm{E} 2$ \\
\hline $\mathrm{Fe}$ & $1.86 \mathrm{E} 3$ & $9.29 \mathrm{E} 3$ & $7.60 \mathrm{E} 0$ & 4.42E0 & $7.68 \mathrm{E} 0$ & 2.35E0 & $7.11 \mathrm{E} 1$ & $a$ & $a$ & $5.94 \mathrm{E} 3$ & $8.50 \mathrm{E} 3$ \\
\hline $\mathrm{Mg}$ & $1.30 \mathrm{E} 1$ & $6.49 \mathrm{E} 1$ & $a$ & $a$ & $a$ & $a$ & $a$ & $a$ & $a$ & $8.88 \mathrm{E} 1$ & $1.27 \mathrm{E} 2$ \\
\hline Mn & $2.49 \mathrm{E} 3$ & $1.24 \mathrm{E} 4$ & $4.63 \mathrm{E}-2$ & $a$ & $a$ & $a$ & $a$ & $a$ & $a$ & $8.27 \mathrm{E} 3$ & $1.18 \mathrm{E} A$ \\
\hline $\mathrm{Na}$ & $3.21 \mathrm{E3}$ & $1.60 \mathrm{E} 4$ & $5.69 \mathrm{E} 4$ & $6.72 \mathrm{E} 4$ & $5.55 \mathrm{EA}$ & $5.95 \mathrm{EA}$ & $1.80 \mathrm{E} 6$ & $9.81 \mathrm{E} 2$ & $7.63 \mathrm{E} 4$ & 2.23E4 & $3.19 \mathrm{EA}$ \\
\hline $\mathrm{Ni}$ & 1.37E2 & $6.84 \mathrm{E} 2$ & $a$ & $a$ & $a$ & $a$ & $a$ & $a$ & $a$ & 5.37E2 & $7.69 \mathrm{E} 2$ \\
\hline $\mathrm{PO}_{4}$ & $1.31 \mathrm{E} 3$ & $6.54 \mathrm{E} 3$ & $a$ & $6.57 \mathrm{EO}$ & $1.63 \mathrm{E} 1$ & 7.37E0 & 2.23E2 & $a$ & $a$ & $a$ & $a$ \\
\hline $\mathrm{SO}_{4}$ & $7.27 \mathrm{E} 2$ & $3.63 \mathrm{E} 3$ & $a$ & $a$ & $a$ & $a$ & $a$ & $a$ & $a$ & $a$ & $a$ \\
\hline Th & $2.49 \mathrm{E} 1$ & $1.24 \mathrm{E} 2$ & $1.56 \mathrm{E} 0$ & $1.10 \mathrm{E} 0$ & $1.35 \mathrm{EO}$ & $1.25 \mathrm{EO}$ & $3.78 \mathrm{E} 1$ & $a$ & $a$ & 5.95E1 & $8.52 \mathrm{E} 1$ \\
\hline $\mathbf{U}$ & $8.07 \mathrm{E} 3$ & $4.03 \mathrm{EA}$ & $a$ & $a$ & $a$ & $a$ & $a$ & $a$ & $a$ & $2.32 \mathrm{E} A$ & $3.32 \mathrm{E} 4$ \\
\hline $\mathrm{v}$ & $7.27 \mathrm{E} 0$ & $3.63 \mathrm{El}$ & $a$ & $a$ & $a$ & $a$ & $a$ & $a$ & $a$ & $a$ & $a$ \\
\hline $\mathrm{Zn}$ & $2.33 \mathrm{E} 2$ & $1.16 \mathrm{E} 3$ & $a$ & $a$ & $a$ & $a$ & $a$ & $a$ & $a$ & $a$ & $a$ \\
\hline
\end{tabular}

${ }^{a}$ Below detection limit. 


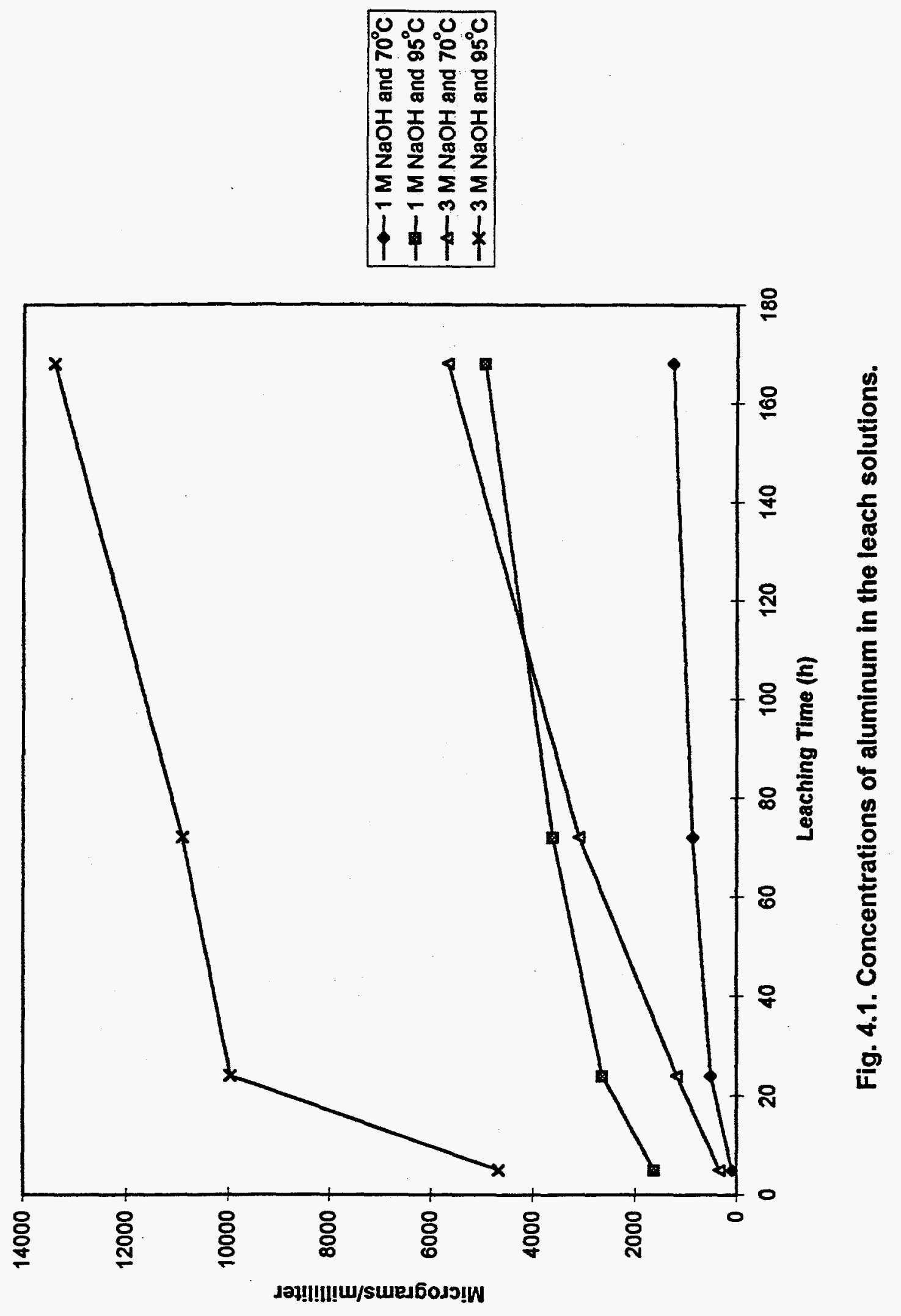




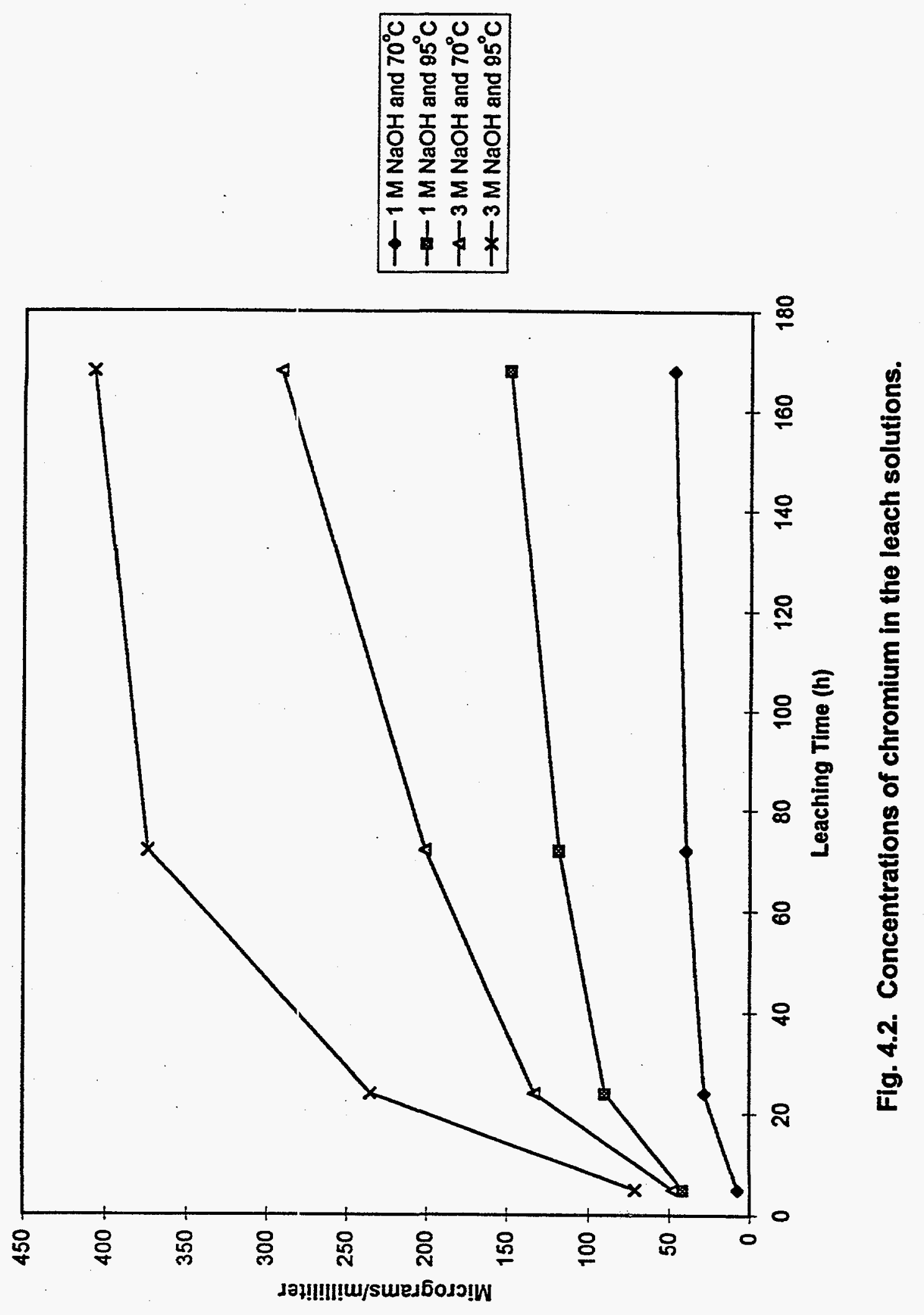



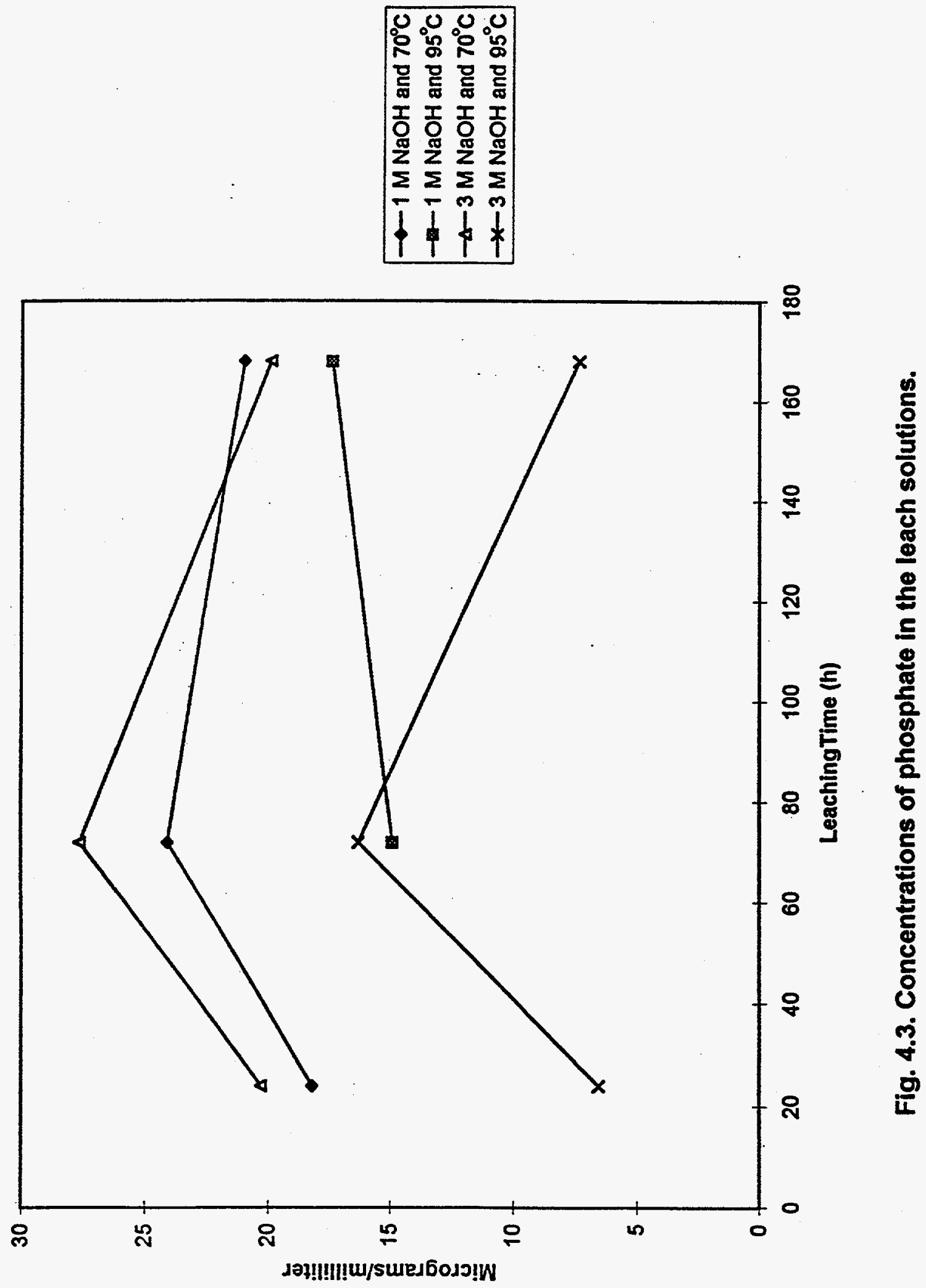
procedure. Since the caustic leaches should only affect aluminum, chromium, phosphate, silicon, and cesium, the new precipitatant(s) can be expected to contain a combination(s) of these components plus sodium and hydroxide. The most likely candidates are sodium aluminosilicates. This speculation is supported by preliminary results of an ESW study on a sludge sample from Hanford Tank BX-112. In this PNNL study, the aluminum and silicon concentrations in the leachates decreased as the leaching time increased, and these results indicated the formation of aluminosilicates. A key difference between the ESW tests with sludge from Tanks S-101 and BX-112 is the ultimate fate of these aluminosilicates. The aluminosilicates in the PNNL tests could not be redissolved, while the aluminosilicates in this study could be dissolved with longer leaching times. This difference shculd not be surprising since different forms of aluminosilicates were observed in a solid state nuclear magnetic resonance (NMR) analysis of aluminosilicates in tank waste simulants (Wang et al., 1995). A thorough understanding of the aluminum-silicon-sodium-hydroxide system is needed before the kinetics of the caustic leaches can be successfully modeled. It should be noted that two studies (Weber, 1982 and Motyka, 1983) have examined the effect of silica on the dissolution rate of aluminum. Both studies reported that hydroxysodalite, an aluminosilicate, would precipitate under certain aluminum dissolution conditions. The temperature of the solution, the silicon-to-aluminum ratio, and the source of the silicon were key variables in the formation of the sodalite.

The conductance and ${ }^{137} \mathrm{Cs}$ activity of each of the leach solutions were measured, and the conductance results are shown in Table 3.2. Since $98 \%$ of the ${ }^{137} \mathrm{Cs}$ was removed during the initial water washes, it is not surprising that the ${ }^{137} \mathrm{Cs}$ activity was essentially the same for each of the leachates. Therefore, ${ }^{137} \mathrm{Cs}$ activity cannot be used to monitor the progress of the caustic leaches when the level of ${ }^{137} \mathrm{Cs}$ is already low. In contrast, nearly all of the changes in conductance values can be directly related to changes in the masses of the leached/washed solids, as shown in Fig. 4.3. Therefore, these results indicate that a conductance probe may serve as a useful process control monitor for the pretreatment of Hanford tank sludges. It should be noted that the aluminum industry currently uses conductance probes to control hot caustic leaches of bauxite. 
Finally, an earlier study at ORNL (Egan et al., 1998) reported that $19 \%$ of the plutonium in a sludge sample from Tank S- 101 could be removed by a $65-\mathrm{h}$ leach with $4 M$ sodium hydroxide at $93^{\circ} \mathrm{C}$. The researchers in the earlier ORNL test used the plutonium activity in the solids before and after the leach to determine the percentage removal. Unfortunately, the researchers did not confirm this surprising result by analyzing the leach solution for plutonium. In the earlier PNNL study on sludge from Tank S-101 (Lumetta et al., 1997), the sludge sample was first leached with $2.5 \mathrm{M}$ sodium hydroxide for $5 \mathrm{~h}$ at $100^{\circ} \mathrm{C}$ and then leached with $2.7 \mathrm{M}$ sodium hydroxide for $100 \mathrm{~h}$ at $100^{\circ} \mathrm{C}$. No plutonium was detected in the leach or wash solutions even though the plutonium analysis of the solids indicated that a large portion of the plutonium was removed by the solutions. Since the plutonium analysis of the liquids should be the more definitive test for plutonium removal, the PNNL researchers reported that at least $96 \%$ of the plutonium remained with the solids. In this study, plutonium removal with $1 \mathrm{M}$ sodium hydroxide at $70^{\circ} \mathrm{C}$ and $1 \mathrm{M}$ sodium hydroxide at $95^{\circ} \mathrm{C}$ were $<2.0 \%$ and $<1.0 \%$, respectively. Since plutonium was not detected in the leach solutions, the earlier claim that the ESW can leach plutonium from a sludge sample from Tank S-101 cannot be substantiated.

\subsection{ANALYSIS: WATER WASHES ON SLUDGE FROM TANK C-103}

The initial water washes of the 83.19-g sludge sample from Tank C-103 indicate that this sludge sample contains a much smaller percentage of water-soluble salts than the sludge sample from Tank S-101. The wet weights of the washed solids after the first, second, third, and fourth washes were $90.54,85.48,84.00$, and $80.66 \mathrm{~g}$, respectively. It is important to note that the initial wash increased the weight of the solids by $9 \%$. An earlier PNNL study (Rapko et al., 1995) supports this surprising result. At PNNL, $15.3 \mathrm{~g}$ of sludge from Tank C-103 was mixed with $60.3 \mathrm{~g}$ of water. While the PNNL sample was being mixed, $2.34 \mathrm{~g}$ of the sludge slurry was removed and dried at $80^{\circ} \mathrm{C}$ until a constant weight was achieved. The weight of the dried sample was $0.54 \mathrm{~g}$. If the ratio of solids to slurry is applied is applied to the entire slurry, the dry weight of the solids in the slurry would be $17.4 \mathrm{~g}$, which is a $14 \%$ increase from the weight of the initial sample. Apparently, the heat that was generated from the high concentrations of ${ }^{90} \mathrm{Sr}$ and ${ }^{137} \mathrm{Cs}$ 
led to a dehydration of the sludge sample from Tank $\mathrm{C}-103$, and the radiolysis was more effective at dehydration than drying at $80^{\circ} \mathrm{C}$. After the third water wash, the wet weight of the washed solids was still higher than the initial weight of the sludge sample. Finally, the $85^{\circ} \mathrm{C}$ wash was slightly more effective than the last wash at ambient temperature.

The results from the subseçuent water washes at ORNL are in strong disagreement with the PNNL findings (Rapko et al., 1995). PNNL researchers had performed their standard enhanced sludge wash procedure on a sludge sample from Hanford Tank C-103, and they washed a sludge slurry, which contained $0.21 \mathrm{~g}$ of sludge and $0.82 \mathrm{~g}$ of water, with $5 \mathrm{~mL}$ of inhibited water at room temperature for $30 \mathrm{~min}$. The slurry was then centrifuged, and the liquid was decanted. This wash procedure was performed a total of three times. It should be noted that the liquid-to-solid ratio in milliliters per gram was over 75 , while the liquid-to-solid ratio in this current study was less than 6 . The sample was then dried at $80^{\circ} \mathrm{C}$ until a constant weight, which was $0.027 \mathrm{~g}$, was achieved. The PNNL tests indicate that the weight percent of water-insoluble solids was 13.1. However, our conductance and weight measurements indicate that a significant weight reduction is not possible. Since the PNNL researchers indicated that some weight measurements in their tests had inconsistencies, the current wash results are expected to be much more reliable than the FY 1995 wash results from PNNL (Rapko et al., 1995).

The conductance and ${ }^{137} \mathrm{Cs}$ activity of each of the decanted wash solutions were measured, and the results are shown in Table 3.4 and in Figs. 3.5 and 3.6. The trends for conductance and ${ }^{137} \mathrm{Cs}$ activity measurements of the washes with sludges from Tanks S-101 and C-103 were comparable. With both sludges, the largest decreases in conductance and ${ }^{137} \mathrm{Cs}$ activity occurred between the first and second washes. Generally, the conductance and ${ }^{137} \mathrm{Cs}$ activity decreased as the weight of the washed solids decreased. However, the ${ }^{137} \mathrm{Cs}$ activity of the third water wash of the sludge sample from Tank C-103 was $19 \%$ higher than the ${ }^{137} \mathrm{Cs}$ activity of the second wash. Approximately half of the increase could be due to a $9 \%$ increase in the size of the third wash with respect to the second wash. The cther half of the increase could involve experimental error or chemical properties such as kinetics. The fourth water wash produced the expected trends in conductance and ${ }^{137} \mathrm{Cs}$ activity. Therefore, the results with both sludge samples show that 
conductance and ${ }^{137} \mathrm{Cs}$ activity can be used to determine when additional water washes will no longer be effective.

\section{CONCLUSIONS AND RECOMMENDATIONS}

The effects of process variables such as sodium hydroxide concentration (1 and $3 M$ ), temperature $\left(70\right.$ and $\left.95^{\circ} \mathrm{C}\right)$, and leaching time $(5,24,72$, and $168 \mathrm{~h})$ on the efficacy of the ESW process were evaluated with a sludge sample from Hanford Tank S-101. The amount of sodium hydroxide that was used in each of the test conditions was determined by equilibrium calculations. In contrast, most of the earlier studies used an excessive amount of inhibited water and sodium hydroxide in an effort to maximize the removal of aluminum, chromium, and phosphate. If these nonradioactive components can be removed, then the volume of the HLW and ultimately the number of glass canisters with HLW can be reduced. However, DOE has agreed to provide a private contractor with specified quantities of sludge, and the concentrations of key sludge components must be within certain ranges. Therefore, less aggressive caustic leaching may be adequate to meet contract requirements.

For the sludge from Tank S-101, the initial water washes were quite effective. Only $21 \%$ of the initial sludge mass remained after the sludge was washed and dried. While $99 \%$ of the ${ }^{99} \mathrm{Tc}$ and $98 \%$ of the ${ }^{137} \mathrm{Cs}$ were transferred into the wash solutions, all of the ${ }^{60} \mathrm{Co},{ }^{90} \mathrm{Sr},{ }^{154} \mathrm{Eu},{ }^{155} \mathrm{Eu}$, ${ }^{241} \mathrm{Am},{ }^{244} \mathrm{Cm}$, plutonium, and uranium remained with the solids. After the washes, the only removal goals which had not been met were for aluminum and chromium. While each combination of sodium hydroxide concentration and temperature could exceed the removal goal of $64 \%$ for chromium, the $3 \mathrm{M}$ sodium hydroxide leach at $70^{\circ} \mathrm{C}$ failed to meet the aluminum removal goal of $68 \%$ by $3 \%$. The leaches at $95^{\circ} \mathrm{C}$ were clearly more effective at aluminum and chromium removal than the $70^{\circ} \mathrm{C}$ leaches. Overall, the leaches with $3 \mathrm{M}$ sodium hydroxide at $95^{\circ} \mathrm{C}$ were the most effective, even though the leaches used the smallest number of moles of sodium hydroxide per gram of sludge. Leaching time is another critical processing variable because the aluminum and chromium concentrations increased significantly as the leaching times were increased. It is expected that these results will eventually be used by the full-scale 
remediation effort to determine the appropriate ESW processing conditions after the feed specifications for the vitrifier have been set. In the future, similar studies should be performed on additional sludge samples if they represent significant quantities of wastes, which require a more aggressive treatment than the inhibited water washes.

The weight changes of the leached solids clearly demonstrated the complex chemistry involved in the ESW process. With 3 of the 16 tests, the dry weight of the leached/washed solids was greater than the dry weight of the initial washed solids. Since the caustic leaches should only effect aluminum, chromium, phosphate, silicon, and cesium, the new precipitatant(s) can be expected to be due to combination(s) of these components plus sodium, hydroxide, and oxides. The most likely candidates are sodium aluminosilicates. This speculation is supported by the preliminary results of an ESW stucly on a sludge sample from Hanford Tank BX-112. A key difference between the ESW tests with sludge from Tanks S-101 and BX-112 is the ultimate fate of these aluminosilicates. The alurninosilicates in the PNNL tests could not be redissolved, while the aluminosilicates in this study could be dissolved with longer leaching times. This difference should not be surprising since various forms of aluminosilicates were observed in tank waste simulants. A thorough understanding of the aluminum-silicon-sodium-hydroxide system is needed before any attempt to model the kinetics of the caustic leaches will be successful.

Another goal of this study was to evaluate the effectiveness of water washes on a sludge sample from Hanford Tank C-103. In sharp contrast to the washes with sludge from Tank S-101, the inhibited water washes with the sludge from Tank C-103 were not effective, so additional water washes after the retrieval process will not be required. After the third water wash with sludge from Tank C-103, the weight of the washed solids was still higher than the initial weight of the sludge sample. Apparently, the heat that was generated from the high concentrations of ${ }^{90} \mathrm{Sr}$ and ${ }^{137} \mathrm{Cs}$ led to a dehydration of the sludge sample from Tank $\mathrm{C}-103$. In addition, very little radioactivity was removed from the solids. Finally, further ESW tests with this sludge cannot be recommended. The initial ESW test (Rapko et al., 1995) removed only $48 \%$ of the aluminum, $11 \%$ of the chromium, and $66 \%$ of the phosphorus. The difficulty in aluminum removal could be due to the high concentration of silicon in comparison to the aluminum 
concentration. The final reason to not pursue further ESW tests is Tank C-103 belongs to a SORWT group, which contains only a small fraction of the total sludge at Hanford.

The final objective of this study was to test potential process control monitors during the water washes and caustic leaches with actual waste. The ${ }^{137} \mathrm{Cs}$ activity and conductance were measured for each of the water washes and caustic leaches. The ${ }^{137} \mathrm{Cs}$ activity can be used to monitor the progress of the water washes and caustic leaches if the solids contain appreciable quantities of ${ }^{137} \mathrm{Cs}$. The ${ }^{137} \mathrm{Cs}$ concentration of the washed solids in the test with Tank S-101 sludge was $1.20 \mathrm{E} 5 \mathrm{~Bq} / \mathrm{g}$, and this level of activity was insufficient to monitor the effectiveness of the caustic leaches. Fortunately, the conductance probe encountered fewer difficulties. Nearly all of the changes in conductance values can be directly related to changes in the masses of the solids. Therefore, these results indicate that a conductance probe can serve as a useful process control monitor for the pretreatment of Hanford tank sludges. It should be noted that the aluminum industry currently uses conductance probes to control hot caustic leaches of bauxite. These preliminary results indicated that the conductance probe should be further developed as a process control monitor.

\section{ACKNOWLEDGMENTS}

This task was sponsored by the U.S. Department of Energy through the Office of Science and Technology's TFA under U.S. Government contract DE-AC05-96OR22464 with Lockheed Martin Energy Research Corporation. The work was performed at the Oak Ridge National Laboratory under the auspices of the Chemical Technology Division.

\section{REFERENCES}

Collins, J. L., B. Z. Egan, E. C. Beahm, C. W. Chase, and K. K. Anderson, Characterization and Leaching Study of Sludge from Melton Valley Storage Tank W-25, ORNL/TM-13445, Lockheed Martin Energy Research Corp., Oak Ridge National Laboratory, 1997.

Colton, N. G., Sludge Pretreatment Chemistry Evaluation: Enhanced Sludge Washing Separation Factors, PNL-10512, Pacific Northwest National Laboratory, 1995. 
Colton, N. G., Status Report: Pretreatment Chemistry Evaluation FY 1997-Wash and Leach Factors for the Single-Shell Tank Waste Inventory, PNNL-11646, Pacific Northwest National Laboratory, 1997.

DeMuth, S. R., Estimating Heel Retrieval Costs for Underground Storage Tank Waste at Hanford, LA-UR-96-3038, Los Alamos National Laboratory, 1996.

Egan, B. Z., B. B. Spencer, and C. W. Chase, Caustic Leaching of Sludges from Selected Hanford Tanks, ORNL/TM-13500, Lockheed Martin Energy Research Corp., Oak Ridge National Laboratory, 1998.

Hill, J. G., G. S. Anderson, and B. C. Simpson, The Sort on Radioactive Waste Type Model: A Method to Sort Single-Shell Tanks into Characteristic Groups, PNL-9814 Rev. 2., Pacific Northwest National Laboratory, 1995.

Jensen, R. D., Enhanced Sludge Washing Evaluation Plan, WHC-EP-0805, Westinghouse Hanford Company, 1994.

Keller, J. M., J. M. Giaquinto, and A. M. Meeks, Characterization of the MVST Waste Tanks Located at ORNL, ORNL/TM-13357, Lockheed Martin Energy Research Corp., Oak Ridge National Laboratory, 1996.

Lumetta, G. J., B. M. Rapko, M. J. Wagner, J. Liu, and Y. L. Chen, Washing and Caustic Leaching of Hanford Tank Sludges: Results of FY 1996 Studies, PNNL-11278, Pacific Northwest National Laboratory, 1996.

Lumetta, G. J., I. E. Burgeson, M. J. Wagner, J. Lui, and Y. L. Chen, Washing and Caustic Leaching of Hanford Tank Sludges: Results of FY 1997 Studies, PNNL-11636, Pacific Northwest National Laboratory, 1997.

Motyka, T., Aluminum Dissolution in the Presence of Zeolite, DPST-83-896, DuPont, Savannah River Laboratory, 1983.

Rapko, B. M., G. J. Lumetta, and M. J. Lumetta, Washing and Caustic Leaching of Hanford Tank Sludges: Results of FY1995 Studies, PNL-10512, Pacific Northwest National Laboratory, 1995.

Rapko, B. M., C. H. Delegard, and M. J. Wagner, Oxidative Dissolution of Chromium from Hanford Tank Sludges Under Alkaline Conditions, PNNL-11571, Pacific Northwest National Laboratory, 1997.

U.S. Department of Energy, Integrated Database Report-1995: U.S. Spent Nuclear Fuel and Radioactive Waste Inventories, Projections, and Characteristics, DOE/RW-0006, Rev. 12, 1996. 
Wang, L., B. C. Bunker, Y. Su, J. J. Kingsley, L. Song, S. Li, and J. Liu, Solid State NMR Analysis of Aluminosilicates in Tank Waste Simulants, TWRSPP-95-034, Pacific Northwest National Laboratory, 1995.

Weber, E. J., Aluminum Hydroxide Dissolution in Synthetic Sludges, DP-1617, DuPont, Savannah River Laboratory, 1982. 

ORNL/TM-13655

\section{INTERNAL DISTRIBUTION}

\author{
1. E. C. Beahm \\ 2. C. W. Chase \\ 3-7. J. L. Collins \\ 8. A. G. Croff \\ 9-23. R. D. Hunt \\ 24. R. T. Jubin \\ 25. C. P. McGinnis
}
26. L. E. McNeese
27. B. B. Spencer
28. C. F. Weber
29. T. D. Welch
30. Central Research Library
31. ORNL Laboratory Records-RC
32-33. ORNL Laboratory Records-OSTI

\section{EXTERNAL DISTRIBUTION}

34. Jimmy Bell, 137 Bowspirit Lane, Kingston, TN 37763

35. Penny Colton, Pacific Northwest National Laboratory, Battelle Boulevard, P.O. Box 999, MS K8-93, Richland WA 99352

36. Zane Egan, 103 Lewis Lane, Oak Ridge, TN 37830

37. Randy Kirkbride, Numatec Hanford Corporation, P.O. Box 1300, MS H5-27, Richland, WA 99352

38. Louis Kovach, Hanford, P.O. Box 1970, K6-51, Richland WA 99352

39. Gregg Lumetta, Pacific Northwest National Laboratory, Battelle Boulevard, P.O. Box 999, MS P7-25, Richland WA 99352

40. Jacquie Noble-Dial, U.S. Department of Energy, Oak Ridge Operations Office, P.O. Box 2001, Oak Ridge, TN 37830-8620

41. Bryan Rapko, Pacific Northwest National Laboratory, Battelle Boulevard, P.O. Box 999, MS P7-25, Richland WA 99352

42. Wally Schultz, W2S Company, Ins., 5314 Arbustos Court, NE, Albuquerque, NM 87111

43. David Swanberg, SAIC, MS H0-50, 3250 Port of Benton Blvd., Richland, WA 99352

44. John Swanson, 1318 Cottonwood Drive, Richland, WA 99352

45. Don Temer, Los Alamos National Laboratory, NMT-1 CMR, MS G740, Los Alamos, NM 87545

46. Major Thompson, Westinghouse Savannah River Compāny, Building C-140, Room 773-A, Savannah River Technical Center, Aiken, SC 29808

47. George Vandegrift, Argonne National Laboratory, 9700 South Cass Avenue, Building 205, Argonne, IL 60439

48. Ray Wymer, 188-A Outer Drive, Oak Ridge, TN 37830 
49-56. Tanks Focus Area Technical Team, c/o G. C. Notch, Pacific Northwest National Laboratory, Battelle Boulevard, P.O. Box 999, MSIN K9-69, Richland WA 99352

57. Tanks Focus Area Field Lead, c/o J. A. Frey, U.S. Department of Energy, Richland, Operations Office, P.O. Box 550, MS K8-50, Richland, WA 99352 